\title{
THE HABITS OF THE SALMON
}

MAJOR TRAHERNE 


$$
\text { Sherloy He.fale }
$$




\section{QL 638.52T76 Unıversity Library}

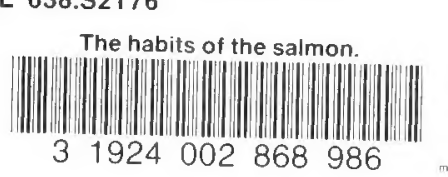




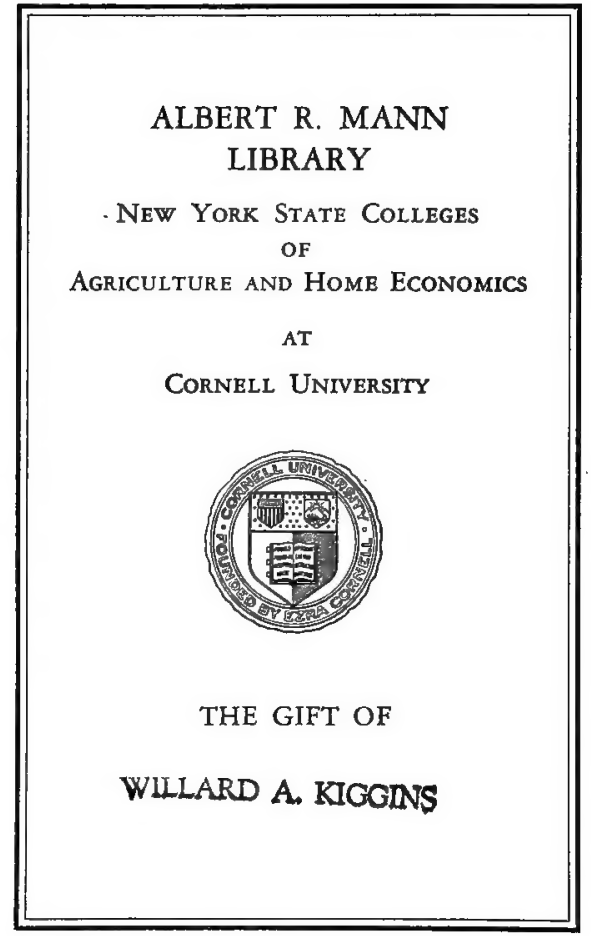




\section{THE HABITS OF THE}

\section{SALMON}

JOHN P. TRAHERNE.

LONDON-CHAPMAN AND HALL,

LIMITED.

1889.

[All rights reserved.] 


\section{QL \\ 638 \\ 52 \\ T16 \\ 360786}

LONDON :

- PRINTEd by GILEERT and RIVINGTON, limited, ST. JOHN'S HOUSE, CLERKENWELY ROAD. 


\section{- INTRODUCTION.}

Perhaps it is unnecessary for me to offer any elaborate excuse for coming forward with another book about salmon. Of all the fish that fall victims to our skill, salmon are the most interesting by reason of their size, strength, and gameness, the difficulty of their capture, and the romantic scenery of the districts in which, during their periodical returns to fresh water, we have to seek them. Nor, in view of its gastronomic excellence, its rapid growth and great fertility, will the economist cease to remind us that the salmon is an important article of food, and of great commercial value. Yet angler and economist alike may fairly doubt whether our present salmonlaws are "within measurable distance of " what they 
could be and should be. Do these laws afford the greatest possible scope, encouragement, and protection for the rapid propagation of the fish, and secure a distribution of the harvest amongst all the various proprietors according to their equitable interests? Are there not most important facts, as yet without their due, or perhaps any, influence on the statutes regulating the preservation and capture of salmon, that point with certainty to a greater supply of fish as the result of improved legislation?

In calling attention to such questions as these, and making my observations on them in the following pages, I do so from a standpoint different from that usually adopted by writers on the subject. Much valuable information has been gained about the salmon during his stay in fresh water; but there is still abundant room for contributions from the practical side as well as from the scientific.

Questions relating to the natural history of the fish have been, and are, constantly engaging the attention of able men of science. To that class I do not pretend 
to belong. I am merely an angler of long and varied experience; and during my angling visits to various rivers, I have had such opportunities of studying the habits of salmon and of acquiring valuable information on many of the topics relating to them as few other fishermen have enjoyed.

I do not for a moment expect my readers to agree with all the conclusions at which I have arrived. On the contrary, it is my desire to provoke practical and reasonable discussion upon many controverted questions. If others who may have kept their eyes open while they fished were to contribute their quota to the present stock of knowledge, we might eventually hope to arrive at some kind of unanimity, and a day might come when upper proprietors, proprietors of net-fisheries, and anglers, would shake hands and meet in harmony to discuss new projects for their own mutual benefit.

Pending the arrival of such a millennial happiness, I venture to send out this little volume as a slight contribution towards so desirable an end. 


\section{Cornell University Library}

The original of this book is in the Cornell University Library.

There are no known copyright restrictions in the United States on the use of the text.

http://www.archive.org/details/cu31924002868986 


\section{CONTENTS.}

PAGE

The Habits of the Salmon • . . . . . I I

SPENT Fish . . . . . . . . . . 67

Spawning Salmon, \&c. • . . . . . . . 72

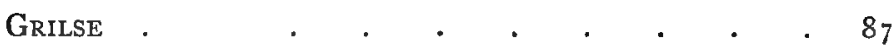

What are the Conditions of a good Grilse Year?. 95

Do SAlMon FEed in FResh Water? . . . . ioI

The Effect of Temperature on the Habits of

SALMON, AS REgaRdS THEIR FEEDING . . . IO4

Parasites . . . . . . . . . . .

Autumn and Winter Emigration of Smolts . . II

What aRe Unclean aNd UNSEASONAble Salmon? - I25

WELL-MENDED KELTS • • • • • • • I3I

Age and Growth of Salmon . . • . . . I 37

Saprolegnia Ferax, commonly Called Salmon Disease ${ }^{4} 42$

APPENDIX A . $\quad$. $\quad . \quad$. $\quad$. . I6I

APPENDIX B . . . . . . . . . I62 



\section{THE HABITS OF THE SALMON.}

No treatise on the art of breeding salmon or that of improving salmon-fishing, can be considered as having a sound basis, unless it starts from, or has direct reference to, the ascertained facts which constitute the natural history of the fish. A knowledge of the habits of salmon, including the emigration of smolts, their nature and food, must come first in order as it does in importance. From the scientist's point of view, to say nothing of the angler's, the subject requires far more investigation and study than it has ever received. We cannot tell for certain whether the spring, summer, and autumn fish are the same breed or not until we are more enlightened than we are at present upon the regular habits of the fish. No one can be absolutely sure that spring fish, for example, obey an invariable law 
in not putting off their journey to fresh water till the autumn; or, on the other hand, that it is in mere caprice that some salmon will, and others will not, leave the salt water at stated times in the year. But whatever ultimately may prove to be the fact in regard to identity of stock, we are quite. justified by convenience in retaining the broad classification, unscientific though it be, which follows the four seasons of the year; and I consider that the ends of January, May, August, and November may well be taken as marking off the respective terms of winter, spring, summer, and autumn fish.

But all rivers are not equally blest in the duration of their supply. Some are more or less frequented all the year round. Into others salmon do not run until summer, and again there are rivers in which not a single one is seen till the autumn sets in. Speaking generally, and with due regard to local conditions, they afford the best sport in spring and summer, but towards the end of August they fall off in this and other respects as their ova become 
developed. For instance, in October their flesh is flabby, gets lighter in colour, and is altogether inferior in edible quality. From this time to the end of the season they are best prepared for food by being salted and smoked. There are, however, exceptions, since along with the gravid autumn fish some are occasionally caught just as good in condition and appearance as those which leave the sea and run into fresh water early in the year. It has happened to myself to catch clean run fish under these circumstances, especially once when fishing the Tay during the latter end of September, 1885. About that time a friend fishing the water just above me, caught three, weighing 36 lbs., 36 lbs., 25 lbs. respectively. I saw them not long after they were taken, and I assert that no finer specimens of Salmo Salar were ever exhibited in Grove's shop in Bond Street, at any season of the year. Throughout the autumn and winter months, as a general rule, not a few of these fresh fish run into the Tay, off and on, just as they 
do into many other waters, and are often caught by the nets when at work for the purpose of procuring ova for scientific purposes.

Loch Tay is frequently stocked with clean salmon in November. Without doubt these are the fish we hear of as being caught somewhat deteriorated in condition when the following angling season opens. It seems strange to call them spring salmon, as they run up during the autumn and winter months, yet on leaving the sea they are similar to the early spring run fish both in shape and colour.

I take it for granted that, in amending the salmon fishery laws, the object of the Legislature was, that salmon should increase in such numbers as must sooner or later reduce the retail price. It could only be then that this most valuable article of nutritious food might be available, when in season, for the poor man as well as for the rich.

This object has partly been attained inasmuch 
as salmon have been found in increased numbers in rivers where they were exceedingly scarce before the fishery laws were' amended. Notwithstanding this fact, the retail price unfortunately keeps prohibitively high in the early part of the season, whilst in the middle of the summer it seldom falls below Is. $6 d$. per pound. The consequence is that poor people do not taste salmon till near the end of the season, when the fish are cheap, and in very poor condition. In all probability the price will never fall very much early in the year, as there are, comparatively speaking, so few rivers in the kingdom that are then adequately stocked with fish. Consequently the supply is a limited one, and is by no means sufficient to meet the demands even of those who can afford to pay the usual exorbitant prices.

If it be true that spring, summer, and autumn salmon are distinct breeds, it is evident that the trouble and expense which have been incurred in the artificial hatching of the ova of the late-running fish, 
with the object of increasing the number of spring or summer fish, have been wasted and thrown away. If, on the other hand, the different migrations are of one and the same breed, or in other words, if the autumn and winter fish breed those which ascend our rivers in the spring and summer months, it is manifest that, although late-running salmon are inferior in edible quality, they are as valuable as spring or summer fish for breeding purposes; therefore, by affording them additional protection, we should increase the numbers of the spring and summer runs, and then a most valuable article of food would soon be brought within the reach of the poor man in summer, if not in spring.

- The question arises, are spring, summer, autumn, and winter salmon distinct breeds or not? That question, I maintain, is of very great importance, not only to the poor man, but also to salmonfishermen in general, as well as to the world at large.

In a very interesting letter to the Field of Nov. 29th, 1885, headed "A Day's Spawning," 
Dr. Francis Day states, "That early ascending salmon cannot be those fish from which we have to expect ova for replenishing the stock of our rivers, and that these early fish cannot develop eggs without another journey to the sea." With all due respect to the opinion of such a high authority, I am of opinion that early ascending salmon are as often as not bred from ova of fish which enter fresh water at any time of year, and I shall be glad to know upon what evidence we can arrive at any other conclusion. Even if it were proved that a certain number of them re-visit the sea before the spawning season, we know that most early-ascending fish stay at home. Take, for example, the River Tay, and what do we find? We find salmon making for Loch Tay all through the autumn, winter, and spring months. In May there is a general exodus of fish from the Loch into the Dochart, a tributary flowing into Loch Tay at Killin, and these remain in the Dochart until the

${ }^{1}$ Since these pages were written, we have had to lament the death of this eminent ichthyologist. 
spawning season is over, when they fall back into the Loch as spent fish. Comparatively few salmon enter Loch Tay after May, as they prefer the warmer waters of the Lyon and other tributaries, and it may be contended that the comparative scarcity of fish in Loch Tay during the summer months is accounted for by the fact of the early fish having returned to sea. Now, if they had returned to sea, where do the fish which spawn in the Dochart come from? There is prima facie evidence that early-ascending fish do not return to sea unspawned, as many clean fish are caught by rods in Loch Tay during the spring months, bearing unmistakable signs of having run up during the previous autumn and winter, and I maintain that the majority of fish which spawn in the Dochart are identical with the early run.

The River Helmsdale (Sutherlandshire) affords some important evidence in relation to the spawning of early-ascending salmon. Not many years ago, netting began in that river on the I I th of February, 
but the spring take was comparatively insignificant both for nets and rods. ${ }^{2}$ But of late years the Duke of Sutherland (the proprietor) has prohibited the nets from being worked until the rst of May, and the result is, that the spring fish have vastly increased in numbers. During the seven years I fished the Helmsdale prior to the Duke's intervention, the average take was not over 46 fish per rod during the spring months; the greatest number caught by myself in any one spring being 82, whilst in another spring I got no more than 16 . Now, I am informed that the average number per rod killed during spring for the last five years has been no less than 125, and that as many as 200 have been killed in the spring by one fisherman. A brief consideration of these facts, even without

${ }^{2}$ The netting was not extensive, and, I was told, barely paid expenses, a statement I had special facilities for testing by personal observation of the daily returns of fish netted. I was convinced that the average spring netting would not exceed 200 fish, but I have just received the most trustworthy local opinion that the average could not have reached that figure for the years in question. 
further details must lead to the inference that the increased numbers of the early running fish may fairly be attributed to the fact of there having been on the spawning beds an increased number of early fish.

Assuming that the sole object of salmon in entering fresh water and making for the upper reaches is to reproduce their species, it is highly improbable that they would so soon take what is often a long and difficult passage, if they have to return to sea in order to enable them to develop their eggs. Is it not more probable that they are instinctively inclined to make the long voyage when they are unencumbered with spawn, and consequently in better condition for travelling? Ova, although discernible in embryo, are never found developed in early ascending salmon; but should this be accepted as evidence that these fish are barren? I think not; and, allowing for those which have lost their way and gone up a strange river, I cannot believe that salmon are in the habit of dropping back to salt water before spawning. To prove they do so, it would 
be necessary to identify them in the tideways and estuaries year after year, by catching and marking them in considerable numbers; but the mere capture of one or two fish in that way would not be sufficient to show that the general habit of early ascending salmon is to return to the salt water unspawned. Where there is such a large body of water as flows in the Tay, it is not an uncommon occurrence for the fish that have taken up their quarters in shallow pools, or in places where they could not live when the water is high, to be carried down stream in a flood to more suitable quarters below. Not many years ago a big flood swept away a great number of fish from the middle waters of the Tay to the deep and comparatively still haùnts below Delvine, and several hundred of them were caught at one station in that locality, and none below it, although the nets were at work all the way down to the tideway. Were it not for these circumstances the capture in question might be considered as showing that the fish were on their downward journey to the sea; but that would be an incorrect view of the case. 
Again, where the annual close time has been altered so as to begin at an earlier date the numbers of early ascending salmon have unquestionably increased. A remarkable instance of this occurs in the Blackwater-a river in the south of Ireland, celebrated for its early salmon. Prior to the year I88 I the annual close time there commenced on the ist of September, and ended on the I 4 th of February; however in I88I it was altered, so as to set in on the r6th of August, and end on the 3 Ist of January. At that time I rented a fishery below Fermoy, and well remember how great was the consternation of many of the rod fishermen at the change decided upon, all of them being convinced that it would be exceedingly injurious to their angling prospects in the spring. But what a mistake they made; for, after the alteration took place, there were far more spring fish killed by the rod for the next few seasons than there had been for some years previously. This increase must surely be attributed to the saving of the lives of hundreds of spawning fish that would have been caught if the nets had been allowed to fish up to the 3 Ist of 
August. I have, however, recently learnt that salmon have become as scarce in the Blackwater, as in other mismanaged rivers of the United Kingdom. It might be contended that in the Blackwater this is a natural consequence of working the nets fifteen days earlier than usual, at the end of the close season; but, in my opinion, the falling off is attributable to the dry summers of the last tw or three years, the drought in 1887 being almost unprecedented. In fact there was little or no rain in I 887 from the beginning of March to October. Very few spent fish could have gone to sea that year, and very few clean fish could have passed up from the tideway, consequently the stock of breeding fish of r 887-8 was reduced to almost nil. The kelts of r 887 were the very fish which were looked to for a supply of clean fish early in the following year, and therefore it is not surprising that the spring fishing, both for nets and rods, in 1888 was the worst we can remember.

It has been stated on very good authority that the result of artificial breeding in the Stormontfield ponds 
has been productive of a great increase of spring fish in the Tay, and if so, it is well to bear in mind that the ova from which the fish in these ponds were hatched, were taken exclusively from autumn salmon, or rather from those caught in fresh water in the lower parts of the streams in November. On comparing notes, and consulting the table showing the date of the commencement of the annual close season for nets on various rivers of the United Kingdom, I notice that early ascending salmon are far more numerous in rivers that have an annual close time commencing on or before the Ist of September, than in rivers where the close time commences after that date. And although this increase may be attributed to other causes, the fact still remains.

Again, very few salmon escape the nets in the estuaries and tideways during the summer, though some pass up during the weekly close time. Those, however, which do make from the tideway are generally captured by the upper nets, within, say, twenty-four hours from the time of their arrival. It follows, therefore, that the breeding stock of these 
so-called summer salmon is often fatally reduced; but in spite of this, large numbers of fish are caught in the estuaries year after year, in the very middle of the season. From whence does this supply come? It surely cannot be supposed that these fish have been bred from the limited number of summer salmon which have so evaded the nets during previous years! It must surely be, rather, that the majority of them owe their existence to either spring, autumn or winter fish.

Many persons assert that spring, summer, and autumn salmon are distinct breeds, but I cannct agree with them, and if the foregoing facts are carefully considered, perhaps the reader may be rather inclined to the presumption that these fish belong, one and all, to the same stock. Many salmonanglers are aware, that the spring fish in all its activity and beauty does not much resemble the unshapely appearance of the comparatively indolent autumn fish; but surely they should not, in the absence of all próof, declare it to belong to a breed wholly distinct from either the summer or 
the autumn stock. In the Blackwater (co. Cork) and the Boyne, and other rivers I could mention, the fish which show themselves during the month of May have more the appearance of overgrown grilse than adult salmon', and would almost give one the idea that they had never been up the river to spawn. Moreover they differ in many ways from the earlier and later run, but if they were compared with each other a still more marked difference would be discernible. Some that come up during autumn are as fresh-looking as spring or summer fish, but it should not be forgotten that nine out of ten of the bright ones are in a gravid state; so I conclude, that their bright appearance arises from their having developed their ova out at sea, while the majority are roaming about the estuary and getting unmistakably discoloured in the brackish water.

The foregoing particulars, though very imperfectly set forth, may give some idea of the cause of the difference in appearance between the various runs of salmon, but must not be taken to support the idea 
that there is any difference whatever in the breed. Let us for the moment consider the dissimilarity between salmon in the parr, smolt, grilse, and adult stages, bearing in mind that every member of the Salmo Salar family undergoes certain transformations at particular periods dating from its birth. Surely it cannot be said that when a young salmon has grown into an adult fish, it will afterwards undergo no further change in appearance: and I would ask those who have considered the matter, whether they can offer any good reasons for the belief that the salmon which run into fresh water in the spring, summer, and autumn, respectively, of a given year, do so in obedience to a persistent instinct, inherited by each fish from its parents, as to the period of ascent from salt water.

It is well known that salmon which have reached the adult stage undergo certain changes in appearance as they grow older; a fact that may account for some errors made in regard to the question of breeds. With cattle we observe 
that counties in the United Kingdom have their own distinct breeds, differing widely from each other in appearance. May we not assume that, in like manner, each river has its own breed of salmon, which, though assuming differences of appearance at various times of the year, yet belongs to one and the same stock? I think so. Some information might be obtained by marking a number of spring fish on making their appearance in fresh water, and by continuing to watch their subsequent movements, viz. their departure from, and reappearance in, fresh water. It is my belief that a winter or autumn fish of one year may run up on the next occasion in the spring, and also that a summer fish might make for fresh water in the spring or autumn; but on this point, I, like many other anglers, have come to this conclusion merely from observation of a character that can hardly be said to amount to actual proof.

The good results which in places have been derived from earlier closing would justify a similar 
alteration in the close time being made on all rivers frequented by early running salmon, at all events where the annual close time commences after the ist of September. The same results would probably be attained in all cases, and therefore proprietors of net fisheries would be amply compensated for any loss sustained by their having to leave off fishing earlier than usual. For there would certainly be more gravid fish left to breed, and thus the stock would be increased during the early part of the season, when the fish are not only in their best condition, but fetch the highest price.

The question, however, of the annual as well as the weekly close time has, as long as I remember, been a source of ill-feeling, causing endless disputes between the upper proprietors of fisheries and those above estuaries and tideways. In rivers having a long course, where the nets are not used above the tideway, the present law answers the purpose for which it was intended, and the fish have a free run to the upper waters during the weekly close

$$
\text { C } 2
$$


time. But in other rivers, where the nets are worked above the tideway, it is a different affair altogether, as most of the fish which have passed up from the tideway during the weekly close time are caught by these nets, consequently very few reach the upper waters.

In such rivers there are three interests opposed to each other; there are the interests of the proprietors of estuaries and tideways, of those above the tideway as far as salmon travel during the weekly close time, and of others of the upper waters above those places. Of course the lowest proprietors get the lion's share; they catch fish day and night for at least five days a week during the open season, and in the summer months, when the water is low, hardly a fish making its way to fresh water passes their nets. The netsmen above the tideway are next best off, they begin fishing the very minute the close time ends, and, with the exception of some few fish which happen to have taken up their quarters in impregnable places where the 
nets cannot be used, they catch every fish that comes. But all that falls to the share of the upper proprietors is a small proportion of the few fish that may happen to have passed the lower stations during the weekly close time, and those that reach the district during the annual close season. Of those that make headway in the weekly close time, grilse, by their clever habit of evading the nets, form by far the largest contingent. It would, therefore, appear that the lower proprietors of net fisheries, by virtue of the law as it at present stands, are unjustly authorized to enjoy far more than their share of the spoil, and it is obvious that, unless some better provision is made for the upper proprietors, all moneys expended for the purpose of increasing the number of fish in their waters would be misused and merely benefit the lessees of the net fisheries.

Perhaps the result of some judicious alteration of the law-let alone the facilities afforded by our artificial hatcheries-would amend matters and 
increase the numbers of salmon so as to benefit the upper proprietors. Not that I, in anywise, think it in the power of man to convert a late river into an early one; in other words, to induce the fish, by any artificial means, to run into fresh water one day earlier than has been their usual habit. It is asserted that the River Usk has become an earlier river than formerly, that salmon spawn earlier than they did before they were well looked after, and that there are more fish captured earlier in the spring in consequence. Strict preservation in that river has undoubtedly been the means of increasing the number of both spawning fish as well as spring fish ; but the question is, Do clean fish run up earlier in the spring than they did? Before it can be certain that the Usk is an earlier river than it was, some better proof is wanted to show that there is an increased supply of fish in the months of February and March. I am, however, informed by an old angler, who has fished the Usk for the last twenty years, that, although the fish are more numerous, 
they do not run up one day earlier than they used to. There are other rivers in which strict preservation has been carried on, and although we hear of a large increase of stock in them, we do not hear of any single stream having become earlier by the extra trouble and expense.

I have occasionally seen the upper waters of various districts well stocked with early salmon long before the usual time, but only when the weather had been remarkably mild; their earlier appearance was owing purely to natural causes, and to nothing else. These fish had not really changed their habit. In fact, the early ones are seldom if ever found in shallow rivers, but generally in rivers of a long course which hold deep pools, or in those which are fed by big lakes. The fish take up their quarters in easy running water at the tails of pools or in slack water edging the streams, as well as in long, deep, and still running reaches, but never in rapid currents until the spring is well advanced. A big lake has a great attraction for them, and if they 
find no obstructions as they press onwards, and the weather and water are favourable, they travel straight away for the lake without halting longer than is necessary to rest. The progress they make entirely depends upon the temperature of the water, which during the early spring months is generally lower than at any other time of the year. It is for this reason that, although the height and colour of the water suits them in spring, salmon are apt to tarry in the lower pools and delay their journey until the water gets warmer.

The following facts, the truth of which I can vouch for, may be interesting, as they show the effect the temperature has upon the progress salmon make in their journey from the time they leave the sea. The Thurso and Naver, to give an example, discharge their waters into the sea on the extreme north coast of Scotland, and are about thirty miles distant from one another. The part of the Thurso frequented by early ascending salmon flows out of Loch More, which is a small loch at its head and a 
mile and a half in circumference. There is a course of about twenty miles between the loch and the tideway. There is also a course of about sixteen miles between Loch Naver and the tideway. We know that in both of these rivers salmon are found in the month of January and sometimes even earlier. Some years ago there were cruives in the Thurso, but for some time past they have not been used, and now there are no such engines in either river. But the habits of the salmon that frequent them differ considerably. For instance, they run into Loch Naver as early as January and February, but not one single fish goes into Loch More until quite the end of March or beginning of April. It is well known that in winter and early spring the temperature of water in big, deep lakes, and rivers which are fed by them, is much warmer than the waters of small shallow lakes; and again, the temperature of water in deep large lakes is lower than that of the sun-heated rivers during the summer months. This accounts for the fact that salmon run earlier into 
Loch Naver, which is a big, deep lake, than into Loch More, which is very small and no more than twelve feet deep in any part, and in which, on account of its shallowness, the water in early spring is several degrees colder than that of Loch Naver.

The Helmsdale and Brora discharge themselves into the Moray Firth on the south coast of Sutherlandshire, and, although somewhat later than the Thurso or Naver, are both spring rivers; in both also there exist obstructions, which, as a rule, prevent salmon from attempting to get over the falls, before a certain time-that is, the third week in April and the first in May respectively.

In my experience of several years on the Helmsdale I never found salmon above the falls before the 20 th of April but once. In that year the weather in spring was unusually mild, and there had been a succession of heavy floods for some weeks previously. That occasion, however, was exceptional; for a close observer says that the habit of the Helmsdale fish has not changed. The Helmsdale flows out of Baden 
Loch - a big lake, one of a chain fourteen miles longand has a course of about twenty miles to the tideway. The falls are situated about midway. There are no big lakes above the falls of the Brora, Loch Brora being some distance below. In spring salmon run up the lower Brora into Loch Brora, then up the river above the loch as far as the falls, but they never try to pass up them until about the 2nd of May, or a fortnight later than they do on the Helmsdale. I account for the difference in the habits of these fish by the fact that there is more snow-water running in the Brora than in the Helmsdale; also by the fact that, as there are no big lakes above the falls in the Brora, the temperature of the water there is lower than it is in the river above the falls in the Helmsdale, whose waters are warmed by the thermal supply flowing from the chain of big lakes at the head of the river.

What do we find in the Shin and the Oykel, both of which rivers empty themselves into the Kyle of Sutherland? Apart from my own ideas I have 
gathered considerable information from reliable sources. I refer chiefly to private communications made to me by anglers who have fished the rivers for years ; and to "The Angler's Guide to the North of Scotland," by the late Mr. Andrew Young, of Inverness-shire. Mr.Young's remarks on these rivers may be absolutely depended upon; moreover, his description of the Shin and Oykel is instructive and very interesting. The work clearly shows the effect of temperature on the habits of the early running fish. With regard to the Shin, the author remarks : "From its short course between Loch Shin and the tideway in the Kyle of Sutherland, its temperature is several degrees higher in the winter than the waters of the Oykel and Cassley, with which it mingles on entering the Kyle, and the temperature is several degrees lower in the summer than the waters of these long, sun-heated, hill-collected rivers. All these variations are ascertained by means of instruments at different seasons of the year. But even without them we see these rivers completely covered with ice 
in the course of the winter, when often no ice is seen on the Shin. These changes have their due effect on the salmon entering the river at different seasons, for their acute sensitiveness soon leads them to the warm side of the estuary and the river from which the warm water flows. It is well known that salmon during the winter and spring months, when the water of the warmest river is always cold, run on the sunny side of the estuary, that is, as much as possible on the north side, for, from the low course of the sun at that season, the sunbeams reflect strongest on the north side, and there during that time the run of fish is to be found. In the summer months, that is after the Ist of May, the fish run on quite the opposite side of the estuary, the high temperature of the water at that time inducing them to seek, and as much as possible to get under, the cool shade of the south banks, where there is the least influence of the sunbeams. In large rivers and estuaries it has always been found that netting has been most successful on the north side during spring and winter, and on the south side 
during the summer. There are many good fishing stations on all such rivers and estuaries, where no fish can be caught earlier than the ist of May, while just opposite such stations, the north side, makes a successful spring fishing. It may be asked here, when so many salmon rivers run into the tideway of this Kyle, What is the reason that the Shin is the only river that produces early salmon? The reason is that which has been explained before, 'The high temperature of the Shin in winter.' That is the season in which the ova are embedded in the gravel in the river, and the hatching of the young fish is more hastened here than in other rivers of a very low temperature. The same cause affects the fish in the same proportion in all their upward stages, and as all these rivers have their peculiar race of fish, which return to the river in which they have been bred, it entirely accounts for the Shin producing early salmon, and the other rivers not. This river issues from Loch Shin at Lairg, and its whole course, with its windings, is only between six and seven miles long. 
The river may be said to be in two sections divided by a large fall, over which the fish can ascend with considerable difficulty, but not in all sizes of the water. The only sure and safe chance in getting over is when the river is in a middling size, neither too high nor too low. The principal angling during the spring months is from the big fall, as this is called; for the reason that, about a mile farther down, the river runs over a low ledge of rock, known by the name of the little fall, which from appearance should be no obstruction to the fish at any season; but it is remarkable that they never go higher up the river than the little fall earlier than April, and whatever size the water may be, salmon never attempt to go over the big fall earlier than the middle of May, and very often not before the beginning of June."

We find, therefore, that on the Shin, Oykel, and Cassley, the temperature has exactly the same effect on salmon moving upwards as it has in other rivers I have already mentioned. On the Cassley and Oykel, which are not fed by big lakes, the fish are 
seldom to be found until April, by which time the water becomes much warmer.

The temperature of the water in the Shin-a river flowing from a very large lake-is probably as high as or even higher than that of either the Helmsdale or Brora. It may, therefore, be asked, How is it that salmon do not attempt to pass over the fall in the Shin until a later date than they do in the other two rivers? The answer is this: the fall presents far more opposition to the passage of the fish than the falls of the Helmsdale and Brora, so much so that it would appear that in a dry season, such as that of 1887 , fish could not pass over the big fall in the Shin until after the back end of the open season.

In the Aberdeenshire Dee, which is a first-class early river, the same effect is produced by the temperature of the water on the movements of salmon as in other rivers. Should it be cold in the winter or spring, and plenty of snow have fallen, the fish tarry in the lower pools; but after a mild winter 
they make for the Ballater district, and are often found as high up as Braemar on the opening day of the rod fishing. I may, however, mention that there are no obstructions in the Dee.

Now take the Tay, into which clean fish run all through the year, more or fewer, according to the results of the netting operations in the tideway. When the netting season terminates all the salmon move upwards, and have a free passage all the way to Loch Tay, into which they continue to run so long as the weather is favourable. But directly frost and snow set in, all the fish which have left the tideway remain in the lower pools until the weather becomes milder. In winter and early spring the temperature of the water in this Loch is several degrees warmer than it is in the Lyon which joins the Tay a little below Taymouth Castle, whilst the water in the Lyon is warmer than it is in the Loch during the summer months. For this reason, salmon do not patronize the Lyon nor other tributaries in winter and early spring, but run into Loch Tay. When 
the winter is very mild, and is not accompanied by snow-a state of things which, however, rarely happens-the early fish frequent the Lyon and are more numerous there than in the Loch. This is because the water in the Lyon is the warmer of the two. Indeed, it is well known that comparatively few salmon run into Loch Tay between May and autumn; and I am informed by an authority, who has fished the waters of the Tay for thirty seasons, and who for some years was the Marquis of Breadalbane's fisherman, that during his experience he neither caught nor heard of the capture of more than one grilse kelt in the Loch itself. Grilse as well as salmon avoid the colder water of the Loch all through the summer months, and take up their quarters in the Lyon. They sometimes congregate previously above the outlet near where the Lyon runs out of the Loch, but they seem to go no higher; and supposing my information to be correct, it seems that even the salmon which have previously run into the Loch, leave it after May for the warmer waters of the Dochart, 
and remain there until the spawning season is over.

- I have endeavoured, so far, to describe the habits of early running salmon which frequent a few of the cold Northern rivers, and in my opinion the arguments in regard to their habits hold good on other rivers all over the kingdom. The early fish are similariy affected by temperature in our southern rivers, where the progress they make upstream is slow during intęnse cold. In fact, under such circumstance, they never travel to the upper waters until the spring is well advanced and the warm weather has set in.

In regard to Irish waters, the whole business appears to be a different matter altogether, but it is not so in reality. The climate of Ireland during the winter and early spring is much warmer than it is in England or Scotland, in fact it is often summer weather in the extreme south long before vegetation is affected by the sun in the North of Scotland. On that account the temperature of the water is of course warmer in 
Ireland at the time, and has its due effect on the upward progress of spring fish.

Let us take a few instances. The Lee (Co. Cork)in which, amongst other obstructions, there is one of vital importance-is a noted river for early fish, but it requires a high flood to enable them to pass over that most formidable obstacle, known as the Pipe weir, which is situated near the tideway. If, however, there is water enough, the whole river from Cork to Macroom, some thirty miles in extent, is usually stocked with spring salmon by the Ist of February, that being the opening day of the rod season.

The Blackwater runs through the counties of Cork and Waterford, and is really a first-class spring river. Although the uninitiated may imagine that an obstruction is formed by the fishing weir at Lismore, it is not so, for there is a "Queen's gap," through which every fish that escapes the nets can freely pass. There is a weekly close time of forty-eight hours on this river, and so the pools are gene- 
rally well stocked with clean fish early in the year. Again, there is the Mill weir at Clondulane, which is about twelve miles distant from the tideway, and aiso the famous weir at Fermoy, some four miles beyond it, both of which are obstructions of a troublesome character; still I have seen hundreds of salmon early in the year pass over the fall at Fermoy. They must have reached there by first getting over the weir at Clondulane. Many of these fish find their way to the upper waters, even as high as Mallow-a town at least thirty-six miles from the tideway at Lismore. There are salmon ladders erected on both weirs, but the fish never appear to make use of them. In the year I 882 far more spring fish were killed in the upper than the lower waters, except at Careysville; but the winter and early spring had been exceptionally mild, and that accounted for the upper waters being stocked in such unusual numbers so early in the season. Taking an average, however, although a fair number of fish are found in the upper waters very 
early in the spring, these particular districts are never well stocked until April.

The Boyne (Co. Meath) is also a celebrate $\mathrm{d}$ early river, and notwithstanding ten mill weirs situated between Navan and the tideway, spring salmon are always caught by anglers as high up as that town on the Ist of February, which is the opening day for the rods. Some few fish run past Navan, whilst the majority make for the Blackwater-a large tributary of the Boyne, running in just below the town. A short distance above the junction of the Blackwater, and we come to another weir. It is in the stream below this weir that the first salmon of the season is generally caught. I was once at a loss to say why salmon always went into the Blackwater earlier than into the Boyne above Navan; but later on I found that the Blackwater is fed by a large lake, and that the Boyne has none at all. I am now enabled to state, through the kindness of a friend, what the exact temperature of the water was in these two rivers 
during the month of January, 1887. The test was made in both cases just above where the waters meet at Navan. Here is the result.

\begin{tabular}{|c|c|c|c|c|c|c|c|c|c|}
\hline \multicolumn{5}{|c|}{ Boyne. } & \multicolumn{5}{|c|}{ Blackwater. } \\
\hline Tanuary & & $\ldots$ & $3^{6}$ & grees. & January & & $\ldots$ & 37 & grees. \\
\hline " & I7 & $\ldots$ & 35 & $"$ & " & I 7 & $\ldots$ & 35 & $"$ \\
\hline , & $2 \mathrm{I}$ & $\ldots$ & 36 & $\eta$ & " & $2 \mathrm{I}$ & $\ldots$ & 39 & $"$ \\
\hline$"$ & 24 & $\ldots$ & 37 & $"$ & , & 24 & $\ldots$ & $4^{\circ}$ & $"$ \\
\hline " & 26 &.. & 36 & $"$ & " & 26 & $\ldots$ & 39 & ", \\
\hline$"$ & 29 &.. & 37 & " & $"$ & 29 & $\cdots$ & $4 \mathrm{I}$ & $"$ \\
\hline ", & $3 I$ & $\ldots$ & 37 & $"$ & , & $3 \mathrm{I}$ & $\ldots$ & $4^{2}$ & $"$ \\
\hline brua & ry 2 & $\ldots$ & 37 & $"$ & Februar & & $\ldots$ & 42 & $"$ \\
\hline
\end{tabular}

It will be seen from the above statistics that the temperature of the water in the Blackwater averaged three degrees higher in January than that in the Boyne. And so I can satisfactorily explain why salmon appear in the former river earlier than they do in the Boyne above Navan.

Independently of other instances to which I could well refer, we have already three rivers in Ireland through which the earliest spring salmon directly travel for the upper waters in spite of all obstruc-. tions. But this is not surprising, although with 
similar obstructions not one would find its way to the upper waters of most rivers in the north of Scotland until much later on. I am convinced that there can be but one reason for this, and none other, namely, that the climate of Ireland by being much warmer than that of Scotland, the temperature of the water is higher. But the rule as to temperature in that country does not apply everywhere exactly alike; for instance, if we take the Erne and the Bann, we find that the habits of the fish are altogether different. The Erne is fed by two large lakes, the upper and lower Lough Erne, whilst the Bann is fed by the largest lake in Ireland, Lough Neagh, and yet few if any fish find their way into Lough Erne before May, or into the Bann before autumn. With all that, they run through the Bundrowse river early in spring into Lough Melvin, which is only a short distance south of Ballyshannon, as they do into the Bush-an insignificant river, not fed by any lake at all, about the same distance from Coleraine. How do 
we account for this? By the simple fact that the fall at Ballyshannon is a far more formidable obstruction than the others to which I have referred. Salmon will not face the Ballyshannon fall, when the temperature of the water is low, even in that mild climate, and this is invariably the case during the early spring months. It would be interesting to know why the Bann, with its capabilities of holding early salmon, and having no formidable obstructions, is such a late river; whilst the Bush, a little river hard by, with no lake, is well stocked early in the year. This may be accounted for by the presence of cold springs in Lough Neagh, which of course lower the temperature of the water in the river so much as to prevent salmon entering it early in the season. The same cause and effect may possibly be the case with the Erne. I remember, some years ago, when I had shooting on the banks of Lough Erne, with its islands which were the favourite resort of woodcocks, that on one occasion the Lough was frozen over, and that 
the whole of my friends were able to cross the ice to the islands for some days, without risk. It is very seldom that large lakes are frozen over in Ireland, and, if I remember rightly, Lough Erne was, on the occasion referred to, an exception. This is perhaps worthy of note, and not out of place here. It reminds me that salmon never run into Loch Earn (Perthshire), out of which the Earn, a celebrated salmon river, flows, and discharges its waters into the tideway of the Tay some miles below Perth. They run up the Earn as far as the loch in great numbers during the autumn, but no farther. This may be accounted for by the fact that there are no spawning grounds above the loch; but a lake has such attractions for salmon, that people may wonder why they do not take up their quarters there for the time being, even if they had to fall back to the river to reach their spawning grounds. But I am inclined to the belief that the coldness of the loch accounts for their absence in it; knowing that they have an objection to the cold springs 
(perhaps mineral), from which the main supply of the water in the loch is derived. It is not easy to account for this in any other way.

If the respective temperatures of the Bush, Bann, Erne, and Bundrowse rivers were taken on a cold day in spring, and we found that the water in the Bush and Bundrowse rivers was warmer than that in the Bann and the Erne, then we could account for the two last-named being later riversthe Bann being the latest river in Ireland.

Even without that information, I think my statements strongly support the assumption that the presence of early salmon and their movements in fresh water is generally dependent upon the state of the temperature. It is as much beyond the power of man to alter temperature as to alter the character of rivers, and therefore any attempt to convert a late river into an early one, or to induce salmon to run into fresh water earlier than is their usual habit would, in my opinion, be an utter failure.

In his book on Salmon Problems, Mr. Willis 
Bund says, "It is not the pace that.salmon can travel that we are concerned with, but the pace they do travel." All salmon fishermen know the pace a salmon can travel after it is hooked, and also that this pace lasts only for a short time, but the usual rate fish travel to their destination in fresh water is, as many know, quite another matter. On entering a river they generally travel up with the tide, and, while in the tide-way, their speed depends upon the rate at which the tide flows. After leaving brackish water they make headway against stream and accommodate their pace to circumstances. Of course if salmon were to rush through a rapid as fast as they could, exhaustion would soon set in. Instinct teaches them this, and they slacken speed, taking advantage of the shelter of rocks or boulders on their way, as well as enjoying a long rest on arriving at weirs or falls, so as to regain strength before passing them. During the early spring months when the temperature of the water is generally very low, although the fish are able to travel as fast as at any time of the year, they never 
do so. Indeed, the progress they make upstream at that time of year is known to be very slow. Later on, when the water gets warmer, they move quicker, and in summer, when it is warmer still, they travel faster than ever. In autumn they also seem to move as fast as they can, but the pace is not so great, because they are encumbered with spawn, and in proportion as their burden becomes developed, their pace becomes slower. By that time the water has usually decreased in temperature, and that alone would have an effect in retarding their progress. I calculate that early in the spring the average pace salmon travel upstream in rapid rivers is, at a rough guess, about onethird of a mile an hour, one mile an hour in summer, and a quarter of a mile an hour in autumn. In rivers containing no rapids and no rough broken water, in other words, rivers of a sluggish nature, the rate of speed is proportionately greater; but I think the fastest average pace salmon travel in any river is seldom, if ever, more than two miles an hour. 
The foregoing estimate is based, not only on personal observation, but also from information received from anglers and others engaged by the water-side on different rivers in the United Kingdom, and I do . not think that my calculations are far wrong. By watching them at various points, and comparing notes afterwards, the pace salmon travel might easily be ascertained. It would be easy to discover the exact hour they reach the first pool, when the journey may be said to have commenced; and with, say, half a dozen watchers stationed at known distances along twenty miles of river, the most accurate information would be forthcoming, and the rate salmon travel could thus be ascertained to a nicety. Travelling salmon generally show themselves at the tails of pools directly they reach them, and at all the most frequented of those places a look-out might be kept. In summer, when salmon travel fastest, and they begin their journey at the very commencement of the weekly close time, some may pass beyond the highest netting-stations, should all 
conditions be favourable; but even when they are caught above those stations, the marketable price does not compensate the casual netsmen for their labours.

Were it asked, "Why is it that we are so concerned with the pace at which salmon travel?" the answer would be, that it is necessary we should have accurate information on this point, in order that we may legislate accordingly, so as to give them plenty of time to pass the highest netting station during the weekly close time, Where nets are not worked above the tideway, the present weekly close time requires no alteration; but where netting is carried on in fresh water, it is almost impossible, except now and then in summer, for the fish to reach the upper waters. The upper proprietors who breed the fish, have much to complain of, for they catch only a certain number of worthless salmon when the nets are taken off, their chances being generally deferred to the end of the season. It is obvious that these proprietors should have a chance of getting a fair share of fish in good condition, 
but so long as the law remains as it is, their chance is poor indeed! I have heard it stated that, although salmon may be scarce on the upper spawning grounds, a great many run up after the annual close season begins, and spawn in the lower waters. Quite so. But there are often far too many fish on the lower spawning grounds. For instance, if we take the Tay, we have enough evidence to show that the spawning grounds of the lower waters of this river are frequently very much overcrowded, and, be it said, the Tay is by no means different in this respect from other rivers of a like character It should be noted here that the annual close time on the Tay is from the 2oth of August to the $5^{\text {th }}$ of February, and the weekly close time from 6 o'clock on Saturday evening to 6 o'clock on Monday morning. If some of the fish were taken from the lower waters and conveyed to the upper, some advantage might accrue, but besides being a very expensive business, and so not likely to be set on foot, it is doubtful whether any good would come of it. The question 
then arises, cannot some arrangement be made between the upper and lower proprietors, which would ensure the passage of an extra lot of fish to the upper waters in the weekly close time? Mr. John Dickson, W.S. of Perth, who has been connected with the salmon fisheries on the river Tay for thirty-three years and more, has written three interesting memoranda addressed to the proprietors of the districts. Recent legislation on the subject to which he refers, finds little favour in his eyes, nor is Mr. Dickson sure that the old laws which were not repealed for four centuries (from I424 to 1828), were not the best of all. The close season, for instance, was only 106 days, i.e. August 26 to December Io. But Mr. Dickson regards Home Drummond's Act of 1828 as being disastrous. By this Act the extension of the fishing season from August 26 (as it was fixed under the earlier régime), to September 14, resulted, in his opinion, in a greater destruction of old autumn fish, and so diminished the supply of the best breeding 
fish in consequence, and he felt sure there were other disadvantages attending the prolongation of the close season to February I.

The Tay Act of $185^{8}$ put back the commencement of the close season to August 26. That alteration gave the fish more time to have a free run; so in Mr. Dickson's estimation it was an improvement. But to give a still more favourable turn, he wanted the fishing season to be so altered as to allow nets-men to begin nineteen days earlier than usual.

The General Act of 1862 lengthened the close time by ten days. Mr. Dickson considers this was the reason why the stock of grilse was reduced in number; and he makes the following observation, viz. that during close time there were so many more fish in the river than it could sustain, that they fed upon their own young in consequence. The remedy he considers to ke a longer continuance of the net-fishing season, and says that it is a mistake of the legislators to attempt to improve the posi- 
tion of the Upper Heritors by shortening the net season. What is really wanted, Mr. Dickson asserts, is an extension of the weekly close time or "Slap" as it is technically termed.

If that were conceded, the fishing season might then go on from January is to August $3 \mathrm{I}$. To close the fishing season too early is to increase unduly the number of old salmon, which require thinning out as much at times as old grouse or old stags.

To close it too late is to reduce the old fish so low in number, as to endanger the future supply of young fish, and that would be doing more harm than good.

Success in breeding thus depends on maintaining, . .. under careful observation, a due proportion between the number of fish and the natural capacity of the spawning-ground.

Mr. Dickson proposes that the weekly close time should be extended to forty-eight hours. Moreover he suggests that the season for the 
nets-men above Perth Bridge should commence on the $1^{5}$ th of January and close on roth of August; and also that the lower nets should commence operations on the $5^{\text {th }}$ of February and cease on the 3 Ist of August. It will be seen that by adopting these dates, both upper and lower fishings would have 158 days of close time.

Some of the rod-fishermen might object to the arrangement, for example, those who have taken the beats just above Perth. They would probably complain that an extension of the weekly close time in summer would be no benefit to them, as at that time of year salmon do not rest in their waters. They might also say that it would be disadvantageous to make any extension of the annual open season below Perth, as they would lose the very fish which at present have a free run. But they would really lose nothing in the end, even if they could not be shown to be gainers at first. It does not often happen that the water is high enough to tempt many fish to leave the 
tideway in August. But it stands to reason that by taking ten days from the upper netsmen, the rod-fishermen would have a better chance of sport, let alone the advantages resulting from the addition of twelve hours to the weekly close time throughout the season. If such an arrangement as Mr. Dickson proposed is ever carried out, and no new netting stations are established above the present highest station, the upper waters would be fairly stocked with clean fish in very good condition. Moreover, miles of available spawning ground, which salmon cannot reach owing to the restrictions in the weekly close time, would be tenanted by a fair number of breeding fish, whilst the lower spawning grounds would not be so overcrowded as they are. After careful consideration, however, I am of opinion. that Mr. Dickson's suggestions might be supplemented with the stipulation that, should any such concession be made to net fisheries, rod fishing should commence on the ist of January. 
I have often heard it asserted that if we fished all the year round with rods, the future supply of fish would not be affected. Quite so. Since the netters in the tideways and estuaries often catch more salmon in one day than the rods do in a whole season, it must clearly be less injurious to our future supplies to allow rod-fishing in January, and put a stop to gravid fish being killed in October. If a landing net were used, no more injury would be done by catching spent fish in January than in February, March, and April. But the use of the gaff should be prohibited, and should not, under any circumstances, be carried before the Ist of May, either on the Tay or on any other river. Rod-fishing should be allowed to commence on Loch Tay with perfect safety on the $15^{\text {th }}$ of November, as a great many clean-run fish generally find their way there by that time; and, when the weather and water favour them, they run into the Loch throughout the winter months. The present angling 
season on Loch Tay is a short one, and commences on the $5^{\text {th }}$ of February. During that and the two following months angling is at its best, but in May it begins to fall off as nearly all the fish run through the Loch into the Dochart, whilst in June the sport is quite at an end. As there are no gravid fish in Loch $T$ ay in November, I never could understand why the law should prohibit the capture in that month of fish by far superior in quality to those imported into our markets from the Rhine during the winter months, and allow rod-fishing on the Tweed and other rivers during November, when nine-tenths of the fish caught are in a gravid condition. I consider that the close time for rods in the main river and tributaries of the Tay should be from the Ioth of October, at the very latest, to the Ist of January, and from the Ist of August to the $15^{\text {th }}$ of November in the Loch itself. It is to be regretted that people whose function it is to fix the date of the close time in 
the Tay cannot be induced to allow clean salmon to be caught in winter. How could their capture injure our future supply? In no way whatever: The force of this argument has been conspicuously recognized on two rivers, namely, the Thurso and Naver. For years rod-fishermen have been allowed to commence operations on those waters on the I th of January, and success has constantly attended their efforts. In a letter written to me in January, I 888, Mr. Munro, Alnahara Hotel, stated that he killed a clean salmon in Loch Naver on the $3^{\text {th }}$ of that month. Netting has for some time commenced on the Ist of January in the Sligo River in the north of Ireland, and also in the little river running out of Lough Currane at Waterville, in the south, with the result that numbers of salmon are sent to the London and Dublin markets from those places on the opening day of the season. Nor does it appear that this early netting diminishes the stock of fish in the least; on the contrary, anglers have had as good sport in Lough Currane 
of late years as ever. On that Loch the rodfishing does not commence until February; but no reason is given why anglers should not begin operations on the Ist of January. Under all the circumstances the law might well be altered. At this point I would state that I advocate the sport in January only on such rivers as the Tay and others, into which clean salmon return at that season of the year. There are very few gravid fish in the actual catches in January, when the majority of unclean fish caught are spent fish, and have to be returned to the river unharmed. That is far less injurious than the destruction of gravid fish in October; and I am sure every fisherman holds the same view on this point.

The wholesale slaughter by the nets of gravid autumn fish does far more damage to the prospects of a future supply than the capture of the proportionate small number of clean fish at the commencement of the season. If nets were prohibited above and below tideways on all rivers not later than September 
Ist (in many rivers it should be much earlier), and if a free run were allowed past the highest netting stations for at least twelve hours during the weekly close time, I should not attach much importance to the date of the commencement of the net season. But, although a close time such as Mr. Dickson proposes might suit the Tay as well as other early rivers, it would of necessity be quite unsuitable for rivers into which salmon do not run until later on; so the close time in those rivers should be fixed according to their respective requirements. I observe with regret that there is a growing inclination to extend the netting season on some rivers beyond all reasonable limits. The present annual close time commences far too late already ; and in consequence salmon are scarce. Yet several proprietors of fisheries are particularly anxious to get the netting season prolonged; and, knowing that rod-fishermen would not object to such extension of time, they are willing to let the rod-fishing be prolonged for as many days extra as are allowed for the nets. But if they ever succeed, a more suicidal arrangement could 
not be made. In return for the miserable concession of perhaps a fortnight's additional angling for gravid fish unfit for the table, during which time the catch per rod might possibly average, under the most favourable circumstances, one fish per diem, the nets might place to their credit an additional catch of over a thousand breeding fish. The nets might continue to take as many for a time, but the result would soon be that the proprietors would find they had "killed the goose with the golden eggs," as the old saw runs. The fisheries would thus greatly decrease in value, and anglers would discover when too late that their halcyon days of sport were at an end. ${ }^{3}$

I have already stated that there are three conflicting interests on all rivers in which netting is practised above the tideway-rst, those of the net fishings in the tideway and estuary; 2ndly, those of the fisheries above the tideway as far as salmon travel during the weekly close time; and 3 rdly, those of proprietors of fisheries above that district. The first

$s$ The Conway is a notable example of the evil result of an extension of the open season for nets from the Ist to the I 5 th of September. 
two have a common interest in prolonging the open season for net-fishing to the utmost limit of the law, but are yet at variance with regard to the weekly close time. The tideway nets-men naturally wish the weekly close time to be as short as possible, whilst those above the tideway always hold just the opposite view, and want all the time they can get. At present the law appears to be made expressly for the benefit of the latter, at the expense of both tideway and upper proprietors. It is therefore very evident that it is necessary that there should be an alteration in the law as regards the fixing of the weekly close time, even if in no other respect." Boards of Conservators in England are doubtless able, owing to their local knowledge, to form a correct opinion as to what is most suitable to the requirements of their respective rivers; but it should not be forgotten that individual members have their own interests at stake, more or less at variance per-

${ }^{4}$ See Appendix, in which I have expanded my meaning as to close time. It should be borne in mind that in England, conservators have power to make alterations in close times, subject to approval by the Board of Trade. 
haps with those of many other proprietors either below or above them: It is only natural that each member should vote for any scheme that would most benefit himself. Proprietors of net fishings are not unfrequently in a majority at Board meetings; therefore it is nearly impossible that even-handed justice should be meted out to all when the Board assembles. The consequence is that the upper proprietors on all those rivers which are netted above the tideway are the greatest sufferers.

Moreover, even should it so happen that a really good and just arrangement was made as regards close time, Boards of Conservators have no power to put any new rule in force, without the approval and consent of a higher tribunal whose function it is to carefully consider such matters before confirming them.

It is quite certain that the Board of Trade takes a great interest in the prosperity of our salmon fisheries, and may be well up in the subject; but the staff really ought to be increased by practical anglers of varied experience. At present it is impossible for the Board, in addition to its other 
arduous duties, to find time to acquire that intimate knowledge of the requirements of all riversa knowledge necessary to enable it to form a correct opinion on the merits of recommendations of any particular Board of Conservators regarding close time. Its decisions are doubtless influenced to a great extent by the reports of the Fishery Inspectors. Still, the fact remains that the Board has power to ignore any and every proposal, however desirable it might be that the recommendations of the Conservators should be carried out; and for this very reason there is also the risk that a recommendation from the same source, wholly opposed to the real interests of their river, may find favour in the eyes of the Board, and carry disastrous results. Members of Boards of Conservators are somewhat in the same position as litigants . whose differences have to be settled in a court of law. I hope it may not be considered presumption to suggest that if the Board of Trade do not succeed in obtaining the services of those who have constantly 
fished the majority of our rivers, it might at least determine the close time by a Commission composed of our Chief Inspector as chairman, assisted by two independent practical men, who would inspire the public with confidence by their thorough knowledge of the habits of salmon. Inquiries should be held in localities, not only in the neighbourhood of the tideway, where overwhelming suggestions would be made in favour of the netting interests, but also in convenient localities above there, when witnesses could be examined on behalf of those pro. prietors who could not be expected to give evidence far away from their homes. Were it possible for one to do so, our Chief Inspector is well qualified to perform this duty by himself, but it would be more satisfactory to the public at large if his decisions were backed up by other practical men. These decisions should be final, and not referred to any other authoritv. In all probability my suggestions will meet with little favour in the eyes of proprietors of net fisheries, and I confess that my sympathies 
tend towards upper proprietors, on whose property quantities of fish are annually born and bred, I may say almost entirely for the benefit of the proprietors of net fisheries below and next to the tideway. ${ }^{5}$ If lower proprietors would consent to a reasonable extension of the weekly close time, I am quite convinced that they would be no losers; on the contrary, they would be great gainers in the long run. There would then be so much less need for fresh legislation; but as long as they hold out for such a monopoly as they at present possess, there will be no remedy for the evil until the law is altered so as permanently to remove the question of close time from the sway of partial interests and settle it by independent persons, ready to mete out even justice to all concerned. It may be asked, "Why make such a fuss about close time?" The simple answer is, and I feel confident that many will agree with me, that it is the key to the situation; in other words, to the adjustment of

- This remark applies equally also to Scotland and Ireland. 
the various claims of netting proprietors and anglers, as the prosperity of our salmon fisheries, and the increase or decrease of a most valuable article of food depends in great measure upon the periods fixed to suit each river.

But no river would reap the benefit of an extension of close time unless the stipulations were more rigidly enforced than they are at present. For instance, clean salmon are found during the whole of the annual close season in many rivers, and it is well known that consignments of them are sent to the London and other markets during the fence months. The fish are caught in the estuaries of rivers and on the adjacent coast by nets ostensibly used for catching white fish. It is easy enough to pack them in the ordinary boxes with other fish, and, if I am rightly informed, no one has the power to search or seize those boxes; therefore this illegal traffic in salmon is carried on with impunity. Rhine salmon are frequently imported into our English markets during 
the annual close season, but no one cares how many of the fish that are exposed for sale on the slabs of the fishmongers' shops are genuine Rhine salmon? I am convinced that many of them are bred and born on this side of the English coast and supplied to the trade through secret channels. If the importation of Rhine salmon were prohibited, there would of necessity be an immediate cessation of the sale of poached fish in our markets, as the mere possession of salmon during the annual close season would subject the offender to a heavy penalty, but for obvious reasons we cannot resort to that remedy. It is high time, however, that all injurious traffic in salmon should be stopped; not only the mock imports just alluded to, but also the considerable exports of un. seasonable fish from this country to the Continent where a ready sale for even such tasteless wares is only too easily found. 


\section{SPENT FISH.}

Ir has been proved beyond doubt that the earliest running fish spawn in the upper waters as soon as October, whilst later travellers spawn in corresponding succession up to the end of February. Some few have been known to spawn in March. Pea-fish, i.e. gravid female fish, are caught in almost every river in the spring; there were more of them one year in the Blackwater, Co. Cork, than in any other river I ever fished. I have caught them in that river up to May, but I have never caught or heard of any one catching a male fish in that condition after March, and very much doubt whether any male fish are to be found in that condition at that time. We should gain but little had we to rely on pea-fish for our future supplies, for it is doubtful whether the ova spawned after March ever come to maturity. It is said that the earliest spawning salmon are the first to go to sea as spent fish, and that seems 
natural enough, as they should be the first ready to do so, but whether they actually reach the salt water before the others, in spite of their earlier start, is a very doubtful matter in rivers having a long course. Take the Tay again for example. The earliest run of salmon there occurs in autumn, all of which spawn in the Dochart,-a tributary of Loch Tay. The spawning season commences in the Dochart at the latter end of October and lasts until the middle of December. The spent fish remain in that river for about six weeks after they have done spawning, when they fall back into Loch Tay, and are caught in considerable numbers in the loch by anglers in February and March, but afterwards they are very seldom or perhaps never seen there. The spawning season commences in the main river, the Lyon and other tributaries, in November, earlier or later as the case may be, and numbers of fish which run up later on spawn in the lower waters. If the fish which begin to spawn at the end of 
October and the beginning of November in the upper spawning grounds were ready to commence their seaward journey by the middle or latter end of January, I see no reason why those that have spawned in the lower waters in November and December should not be ready for the salt water in February. The latter having a very short distance to go, would find themselves in salt water weeks before those which have commenced their seaward journey one hundred miles and more up the river a month earlier. It is well known that spent fish travel down the river very slowly. A succession of heavy floods accelerates their journey; but even if that were not so, if the immense numbers of spent fish which have spawned in the lower waters were all to remain stationary, and endeavour to hold on until the army of descending fish from the upper and middle waters and tributaries had passed them, to say nothing of being put about by the ascending clean fish, they would undoubtedly have such an uncomfortable 
time of it, from being constantly elbowed out of their resting-places, as to force them to sea, willing or not. Therefore, it is not improbable that in rivers of a long course the spent fish of the lower waters clear out sooner than those from the upper; the majority of those having spawned in the lowest spawning grounds preceding those which have spawned higher up. The last to reach salt water are the earliest ascending fish which have spawned in the highest spawning grounds. It is possible that those fish which reach the salt water first, acquire the condition of clean fish, and are ready for the fresh water again before others have got there later on. If some of those which reach the sea first re-appear as spring fish on their next visit to fresh water, we could thus account for the fact that additional protection, and artificial breeding of autumn salmon, have been the means of considerably increasing the numbers of our early visitors. But although it is possible that the first kelts that get to 
sea after spawning, return into fresh water bright and silvery before others get a taste of salt water, the necessary time they remain in the sea before returning is a problem as yet unsolved. It has been proved that some fish return to fresh water within four months from the time they were marked, and therefore, we may suppose that spent fish can acquire the condition of clean fish within that time. If all the spent fish reappeared in fresh water as soon as they had recovered their condition, the run of clcan fish into our rivers would last only for four months or thereabouts; but we ail know that at the very time the spent fish go seawards, clean fish pass them to take up their quarters in fresh water, which must have spawned during a previous year. For example, clean fish that are running up in February and March, must at the latest have gone to sea as spent fish in May of the previous year, and calculating that they would acquire the condition of clean fish in about four months, they 
must have remained in the sea for five months after they had recovered their condition.

\section{SPAWNING SALMON, \&C.}

IT is not an uncommon belief that all salmon spawn every year, but that this is an impossibility will at once be seen from the fact that in many of our rivers clean fish run up during the spawning season, their very condition forbidding any possibility of their spawning until the season of the following year. It is, however, quite possible that salmon which leave the sea later on spawn every year; for example, fish which have run up in July, spawning the following autumn, and returning to the sea as kelts, say the following April, may run up again the following August, and spawn again the following November or December, and so on, year after year.

There is not much to say on the habits of salmon during the spawning season that is not already 
known; but the following account sent to me by Mr. Malloch, of Perth, who has passed his life among the salmonidæ, will, I venture to say, be read with interest :-

"On the Tay and its tributaries salmon begin to spawn the first week in November, and a few in October. The first thing to make salmon spawn is a frosty night; they come out of the pools and streams on to a suitable bed for the purpose, where the stones are pretty large and mixed with gravel which does not shift with the action of the water, and always select a place where they can work up. The female turns upon her side and commences to dig her tail into the gravel, and gives seven or eight scoops, turning up the gravel and making the water quite dirty. While she is doing this the spawn is coming from her, from eighteen to twenty roe at every turn. You may wonder how I know this. For ten years I observed it at my father's house, where there is a cutting from the river for the purpose of driving the mill-wheel. Just before it reaches the wheel there is a 
large iron pipe, about nine inches in diameter, run across this cutting for the purpose of taking water from the engine-boiler. When fish were spawning there was always a pair above the pipe, with their tails almost touching it. The pipe was raised above the level of the cutting, the bottom of which, being clay and stones mixed, was so hard that the fish were not able to dig it up. I used to lie down, with nothing but my head exposed, almost touching the water. When the female turned up the soil she put out the spawn, which went round to the back of the pipe, and I had no trouble in seeing how much roe she put out each time. It gradually disappeared behind the pipe, so that before she turned up the soil again it was carried some way down the stream. Year after year fish spawn here. When a fish is newly upon her bed she turns up the soil very often, about once in five minutes, but sometimes oftener; when she has reached a depth of from six to twelve inches she begins to work up stream, and continues working up until she has finished. If the gravel is easily turned up, she 
completes the work three yards above where she commenced. The bed to all appearance looks like a newly-filled grave with a hole at the top of it, which I am quite sure has often been the means of letting the angler in over his waders. The spawn is covered in amongst the gravel, some of it ten inches deep. How the small fry with the little sack can come up from this depth I know not, but they do. When the female leaves off, another very often takes her place, and goes on working up in the same way. This year, I885, I have observed four and five females come after each other and work up in this way until the lead has reached twenty yards long. The male, when not disturbed by other ones, remains beside the female; he never turns up the gravel; the only part you now see him take is to push the female sideways off the bed; as soon as he has done this he returns to his old place, and I presume that is the time he puts the melt on the roe, working at the bottom quite in the bed. If it is a pair of grilse, the male remains pretty quiet; not so with an old male 
salmon, which makes for every intruder that comes near him. I have seen them do this thousands of times, but only once have I seen a salmon take hold of another, and that was only for a moment. I had been watching a pair of salmon quite close to me; a small male grilse was always coming up and remaining behind the bed, and every minute or two the old fellow had a run at him for fifty of sixty yards. On one occasion he took him in his mouth by the middle, but immediately let him go. The next time he did not follow it, yet the grilse went off as fast as it could swim, and came back to the same spot in a few minutes.

The length of time salmon take to deposit their spawn if the weather is favourable is from seven to fourteen days, and no one would credit the quantity of spawn that is washed away by the current. I consider that there are not ten eggs in 100 that get covered up. I counted forty-seven eggs in less than a square foot, and for yards below they were quite as thick; but this was on a splendid bed, where the fish dug deep quite easily. When the river begins 
to subside after the first flood that succeeds the spawning process you can see on the water-mark thousands of eggs that have been washed away from the beds. Conditions of weather and water have a great effect on spawning salmon. When a freshet comes, although a fish has been on the bed for three or four days, she will run up and continue spawning again on a new bed. They spawn every hour in the twenty-four, but the time they are most busy is from about 6 p.m. till about midnight, when they seem to get tired and fall back into the quiet water ; but in the afternoon, from about three, they begin to run up again. Both male and female shift after they have spawned. I have never seen a fish clean spawned out; as they retain a few eggs after they have left the beds. If the frost is very severe, so that it begins to take hold of the bottom (grue we call it), the fish leave off spawning. If the male is taken from the female, and there are plenty of males about, another one takes its place in a few minutes. I have known of over a dozen males taken from the 
side of a female by the gaff in one night. This is a favourite trick of poachers when they see a pair of fish within reach of the gaff. In the spring you will see a great many fish the tips of whose tails and back fins have lost the skin entirely. This is on account of the water leaving them, when the back fin and the tail by being exposed above the surface of the water become frost-bitten. They will crawl up to their beds at night, when there is not as much water as will half cover them. Yellow trout can be seen spawning with sea trout, sea trout with grilse, and grilse with salmon. I may add, that if the weather keeps very cold, the fish that have spawned in November and December will seldom go down before March, and that the females leave first."

I now pass to a kindred topic of general, and, to salmon-breeders, of material interest. I am a firm believer in the theory that salmon, as a rule, return periodically from the sea to the rivers in which they were bred. Those of one river differ in shape and condition from those of other 
waters. Some of them occasionally lose their way and run up strange rivers, perhaps in company with the natives of those rivers. Local fishermen detect strangers at a glance when they meet them, and I have frequently had them pointed out to me. The following is a notable instance. There are three rivers in the south of Norway, the Lyngdal, the Mandal, and the Qvinesdal, that flow into the North Sea, about twenty miles distant from each other. The shape and condition of the salmon that frequent these rivers are so distinctly different that you can tell directly to which river they belong. The Qvinesdal specimen is a lanky, ill-proportioned fish, hardly differing in appearance from an illmended kelt. The Lyngdal salmon is a handsome well-made-up fish, but cannot be compared with a Mandal salmon, which in shape and symmetry is somewhat similar to a Shannon fish, the king of all salmon, as far as shape and condition are concerned. During the five years I fished the Lyngdal I sometimes caught several unmistakable Mandal and 
Qvinesdal salmon. Most conclusive proof that salmon return to their native rivers is furnished in the following letter written by the late Frank Buckland, in Land and Water, of February, I866.

"As all facts relative to the marvellous, but as yet not well-authenticated instinct of the salmon are most valuable, I have great pleasure in placing on record the most curious case I ever heard, which proves beyond doubt that these mysterious children of the flood know their own homes and will return to them through the wilderness of water with the same unerring instinct as do foxes, dogs, and cats, upon land. A friend of mine, who owns a wellknown island on the west coast of Scotland, netted a certain pool in his fishing, and out of a number of fish caught, he carefully marked some twenty or thirty. He then put these fish on board his yacht, and keeping them alive, sailed right round his island then up a creek to the mouth of a river, the salmon were then transferred up the river, which, although close to the river in which they were 
caught, was in no way connected with it, having a different watershed. It is as though the salmon had been carried from one heel of an enormous horse-shoe round to the other heel, and then taken right up into the middle of the horse-shoe and there let loose. During the same season that these fish were transferred, some (the exact number of which will be sent me) of these marked fish were caught in their own pool with the net, and one by the proprietor of the fishing himself, with the rod in the river near the pool. On examining the map, I find that these fish must have come back again to their own river, a circuit of forty miles at least from the lake where they were turned out, and they must have passed six or seven tributaries, up which they did not ascend, although there was nothing to prevent them. What was the wondrous power that guided these fish back to their home?"

It cannot be assumed for one moment that this is a solitary instance, and therefore we must believe that salmon, finding that they have run into strange 
rivers, often return to sea and try to find the way into their relative waters.

The reason why salmon differ so much in shape and condition may be this. As regards shape; it is probable that from the time they were hatched out to the time they went to sea as smolts, they were sustained by food of a more fattening nature in some rivers and tributaries of rivers than in others, and for this reason have developed into larger and better-shaped fish as adults than those which have had poorer food to live on. As regards condition; it is not unreasonable to assume that salmon of every river have their own particular feeding ground in the sea, to which they are instinctively guided on leaving the fresh water, as surely as they are to their native river, when they return there as clean fish. Of course their condition varies according to the quality of the food they get in those feeding-grounds. Fresh-water fish differ in size, shape, and condition in varioes rivers, and this can be accounted for only by the fact that the food 
is more fattening in some rivers than in others. Trout, for instance, are larger and in better trim in rivers running through chalk and limestone than in those whose beds are of a different geological formation. In some rivers they never weigh more than half a pound, but if they are taken thence and put into a stew and fed, they grow quickly, and attain a remarkable size. In the sea, as on land, it is natural to suppose that there are plenty of poor as well as rich feeding-grounds. Salmon thrive and grow fat in rich sea pastures, just as cattle thrive and grow fat on rich land. Poorly-fed salmon never appear shapely and strong, and although the quality of their flesh is not so much affected, the fish rarely attain better proportions than a badly mended kelt. Though we may fairly assume that salmon of each river have their own particular feeding-grounds in the sea, yet it is not possible to verify this supposition, as their ocean haunts have never been actually discovered. Soon after the spent fish reach the sea, they are, in every sense of the word, too deep G 2 
for us, and take up their quarters for the time being where nets cannot reach them. On returning they leave the deep for the shallower waters along the coast, pick their way to the estuary of their own river, and thus reach their native home. Once only have I met with circumstances that would assist me in identifying salmon seen in any locality along the coast as belonging to any particular river. This was in July, I887, when on a visit to Burnham in Somersetshire. During my stay there I was surprised to hear of the numbers of salmon that were caught by the nets day after day in the tideway of the Parrett River, and, being interested in all matters connected with our salmon fisheries, on making inquiries I ascertained that salmon were caught in the Parrett from February to August as well as totchers or grilse, during the summer months. I also learnt that there are no spawning grounds in the Parrett, and that the nearest spawning grounds were in the Taw in Devonshire. A few salmon, however, have been occasionally seen 
spawning in the Cannington River, a small tributary of the Parrett that runs into the tidal portion of that stream below Bridgewater, but they are generally killed by poachers, and I was told that smolts were unknown. Now I believe this account to be true. There is only one water bailiff employed, whose sole duty appears to be to prevent nets being worked during the close time. What, then, are these salmon which are caught in the estuary and tideway of the River Parrett? I do not believe they are natives of any of the neighbouring Devon or Cornish rivers, as salmon rarely appear there until the autumn. It is very certain they do not belong to either the Parrett, the polluted Somersetshire Avon, or Glamorganshire Taff or Ely, and the inference is, they are Severn, Wye, or Usk fish, feeling their way along the Somersetshire coast, en route to their own waters from their own feeding-grounds. I think some of them, instead of crossing the estuary below Burnham, having tasted fresh water, are enticed up the Parrett by the flood tide, never to 
return. The Parrett is scarcely a salmon river, and the estuary is nothing more or less than a natural salmon trap. I have never heard that salmon have been caught in stake nets higher up the Somersetshire coast, probably because on leaving the estuary of the Parrett they soon get a taste of Bristol filth. The Avon discharges its dirty waters into the Bristol Channel, and, to avoid the filth, the fish take a course along mid-channel to the Monmouthshire coast; along which they pick their way to their own respective homes. I would suggest that the one possible chance of ascertaining the identity of salmon caught in the Parrett would be to mark a number of Severn, $\mathrm{W}^{\top}$ ye, and Usk fish, then the capture of any one of these would be quite sufficient for the purpose.

Taking all things into consideration, we might almost be led to believe that the feeding-grounds. of the Severn, Wye, and Usk salmon are situated not very far from the Somersetshire coast. Of course this is mere guess-work, and although it might be 
an interesting matter to know exactly where the feeding-grounds are situated in the sea, the knowledge would not contribute to the solution of any practical question.

It suffices to say that, whereas spent fish are worthless when they leave our rivers, a proportion of them return to us sooner or later in their best condition for the food of mankind.

\section{GRILSE.}

IT would appear that grilse are quite as irregular in their times for entering fresh water as are adult salmon. It is not an uncommon belief that the first run of grilse is made in summer, or early in the autumn of the same year in which they went to sea as smolts. As a matter of fact, we know this to be true in regard to some of their number; but it is equally certain that many do not so return, and remain behind until they have grown into adult fish. The rivers in the south-west of 
England afford valuable evidence touching the irregular habits of grilse. With the exception of the Hampshire Avon, the Test, the Itchen, and one or two others flowing into the sea on the Hampshire and Dorsetshire coasts, the rivers in the south-west district are comparatively late rivers. It is generally understood that, in spring and summer, only a few fish frequent those waters, whilst in some of them grilse are totally unknown, and salmon do not appear until late in the autumn. Peal, as they are termed, run up in considerable numbers in summer, but they are different from grilse; "Peal" being merely a local name for sea trout or sewin in those counties. The Hampshire Avon is a fine large river, into which grilse never are found to run; nor do they appear in the Itchen or Test. I understand from a gentleman living on the banks of the Avon that it has long been a matter of wonder to him and others that grilse are unknown in this and other Dorsetshire rivers; but he said that by the middle of June the streams 
are choked up with weeds down to the mouth, and therefore there was no chance for observation in the summer months. If grilse frequented the Avon, they would be seen on the spawning beds; but in all probability they are unable to make head-way amongst the weeds, and therefore give it up as a bad job. There are, however, few weeds in the Devon and Cornish rivers; in fact there is nothing to prevent the fish from running just as high as they please when the water is not too low.

Again, the Ogmore is a river in Glamorganshire, flowing into the British Channel. Formerly, before its waters were polluted by mine water, gravid salmon ran up this river during the late autumn months, in considerable numbers, but never earlier, and smolts went to sea in vast numbers at the usual season of the year. I lived on the banks of the Ogmore during my younger angling days, and I can state from personal observations that grilse were unknown in the Ogmore, and that it was 
a matter of wonder, to myself and others, what became of the smolts, which must either have remained in the sea until they had grown into adult fish, or have run up another river as grilse. Now there is no river in which grilse are found nearer to the Ogmore than the Usk, neither are there any stake nets for taking salmon between the mouth of the Ogmore and the Monmouthshire coast, so we may therefore assume that few, if any, Usk (or for the matter of that, Wye or Severn) fish make their way to these rivers along the Glamorganshire coast. It is possible that Ogmore smolts may travel across to the Somersetshire coast, and run up as grilse along with Usk, Wye, or Severn fish; but there is not a particle of evidence forthcoming to warrant such an assumption, and for the present we must remain in utter ignorance of their movements. Here, again, we might succeed in acquiring some information by marking the fish.

The same irregularity of habit follows grilse in some of the Norwegian rivers. During the five 
years I fished the Lyngdal, which flows in the southern part of that country, grilse made their appearance only in two of them. On reference to my log-book, I find that no grilse were caught by either nets or rods during the other three years, although there was nothing that I know of to prevent them running up as usual. Salmon spawn in all these rivers just mentioned, and smolts go to sea at the usual time, year after year. But what becomes of them? It is certain that only a very small percentage return as grilse to the waters in which they were bred; still they exist somewhere, or the salmon in those rivers would soon be altogether extinct. We know that vast numbers of parr (irrespective of fish of that name of a similar size and appearance, said to be a distinet species) remain behind in fresh water, after others of the same age have donned their silvery dress and gone to sea. It is not, therefore, surprising that a certain proportion of grilse, as well as adult fish, cease, for some portion of their sojourn in the sea. 
to feel the migratory instinct leading them back to fresh water: I can therefore only conclude, in the absence of any evidence that would lead us to think otherwise, that thousands of smolts remain in the sea, grow into grilse, and still remain there, to grow into adult salmon.

\section{MAIDEN SALMON.}

MAIDEN salmon are those fish which have never been up a river to spawn. In my younger fishing days, I was taught to believe that the term "Maiden" applied only to grilse, and not to adult fish; this was probably because people believed that all the grilse spawned in some river or another. It has, however, been proved of late that large numbers of them remain in the sea and grow into large fish, therefore the term maiden must apply to a certain number of salmon, as well as to grilse. I myself believe that the so-called salmon of limited 
size, which we catch in the spring are maiden fish. The Aberdeenshire Dee is notorious for the small average weight of its spring salmon. Occasionally heavy fish are caught during the spring, but the average weight of the spring run is $7 \mathrm{lbs}$, to $8 \mathrm{lbs}$. I have often asked myself the question, "What fish are these, and when have they been up the river to spawn?" Take, for example, a fresh-run Dee fish, 7 lbs. weight, caught, say, in April, I887. If that fish had been up the river to spawn the previous season, it must have been identical with a smolt that had migrated to sea at the latest during the spring of 1885 , running up the river the same year as a grilse, and returning to the sea as a grilse kelt in the spring of 1886 . Now, supposing that as a grilse kelt it only weighed 2 lbs., is it possible that between the time it went to sea in 1886 and the month of April, 1887, it could only have attained the weight of 7 lbs.? The Dee holds very heavy salmon, as any angler who has fished the river during the autumn 
months can testify. I cannot believe that some of these fish have ever been up the river to spawn; but I think that they must be identical with smolts of the spring of 1886 , which had remained that year in the sea as grilse, and put in their appearance in April, I887, as maiden salmon. That there are maiden salmon of heavy weights, I have no reason to doubt; but how to distinguish them from those which have spawned, appears to me to be a difficult matter. In the course of a discussion I had on piscatorial subjects not long ago with a friend, I was informed that he could easily detect a maiden salmon; but I did not quite gather how he was able to do so. If I were asked to point out a maiden fish of from Io lbs. to 12 lbs. weight, I should select one from a run of May fish in the Blackwater, Co. Waterford, or from a run of fish at the same season in the Boyne. Grilse are seldom seen high up in the Boyne, but plenty are caught in the nets in the estuary, and the tideway above and below 
Drogheda. Those which escape remain in the sea during the spawning season, and I have no doubt, in my own mind, that they are the very fish which make their appearance at the end of April and May. As is the case in the Blackwater, these fish have more the appearance of overgrown grilse than salmon, and in all probability are maiden fish. It must be borne in mind that, like the Hampshire Avon, the Boyne is choked up with weeds after May, and it is therefore impossible for fish to leave the tideway during the summer months, except in a high flood. This may account for so few grilse being seen high up the River Boyne.

\section{WHAT ARE THE CONDITIONS OF A GOOD GRILSE YEAR ?}

IN answer to this question put by Mr. Willis Bund in writing "Salmon Problems," I would say that a good grilse season depends mainly on the 
successful issue of the spawning season two or three years previously. Let us therefore inquire by. what cause the spawn and spawning grounds are liable to be affected. All the spawning grounds may have held their full complement of spawning fish, and may have been well covered with ova before hatching-time. But if heavy floods appear, the eggs are washed away and destroyed. Again, fish may have spawned in good places which, from want of rain, have been left high and dry; that also would be fatal. In a good spawning season, the river remains at a medium height from the time the fish deposit their eggs to the time of hatching. That there are good and bad grilse years goes without saying, but we generally anticipate a good grilse year two or three years after a good spawning season: A good grilse year is also dependent in a great measure on the state of the water at the time they run. There may be plenty of fish which cannot make headway for want of water, and so the greater pro- 
portion are kept back, remain in the sea, and never put in an appearance up the river until the year following. The year 1885 was perhaps one of the best grilse years in the Tay within the memory of man. Grilse average a heavier weight in the Tay than in any river of the United Kingdom, except, perhaps, the Awe, in Argyllshire, where they run up to Iolbs. in weight as early as the month of June. I have seen the cast of a grilse caught in the Tay that weighed 14 lbs., which, I should think, must be the largest on record. In the autumn of 1885 , out of 163 fish killed on the Stanley water by Sir Hussey Vivian, Bart., and myself, only fifty-nine scaled over Iolbs. A great many weighed I I lbs. and I 2 lbs., and were all grilse. Large numbers of them continued to run into the Tay in 1885 up to December, and I was informed on good authority that when the nets were drawn in that year for the purpose of procuring ova for scientific purposes, there were ten grilse to every salmon 
landed. Nearly all were fresh run and quite silvery. Grilse were equally plentiful that year in other fisheries on the Tay and equally scarce in 1886 . Out of 136 fish falling to my own and one other rod on the Stanley water in the autumn of I886, sixty-seven only were grilse, and their weights averaged considerably less than those caught in 1885 ; only two scaled Iolbs., not one of them went 9 lbs., and the remainder only ran from 5 lbs. to $8 \mathrm{lbs}$. It would be interesting to know whether the corresponding spawning seasons of the previous years had been good or bad ones, but with the limited knowledge we at present possess, it is impossible to give a more satisfactory answer to Mr. Willis Bund's question.

Salmon run into fresh water every day in the year, but, so far as my memory goes, there has been no attempt made to explain why grilse never make their appearance before April, and cease to run after October. Thousands and thousands of grilse are supposed to be in condition to leave 
the sea in the winter and early spring months; yet for some unknown reason they never attempt to make the journey to fresh water with the adult fish at that time. It has been proved beyond a doubt that the habits of salmon depend chiefly upon the temperature of the water, and in my opinion grilse do not begin to run until the temperature of the fresh water is higher than in winter. The sudden change from comparatively warm salt water to cold fresh water in winter and spring is injurious to them, as grilse are in the immature stage, and therefore they remain in the sea until their instinct leads them from it. They seem to be aware when our rivers have reached a certain height of temperature, and that is not until April or May, or even the beginning of June. It is true that salmon in the parr stage can live and thrive in very cold water, but then they have been born and bred in it, and therefore acclimatized to the cold; but with all that, they do not care to migrate to sea and be transferred to a 
warmer temperature too soon, as they dislike the sudden change, and swim backwards and forwards in the tideway for a time before they face pure salt water. The case is different with adult spent fish, for they do not tarry in the tideway, but go straight out to sea without fear or delay. Again, in "Salmon Problems" Mr. Willis Bund gives an interesting account of some smolts being transferred from fresh to undiluted salt water which was in the Brighton Aquarium, and the writer states that each fish when dropped into salt water gave three little sobs, just as though the dose was rather too strong. They afterwards coursed rapidly round the tank, and then settled down into their ordinary mood. Surely this experiment may induce us to assume that smolts object to any sudden change of temperature, and therefore it would not be at all surprising if grilse, in their immature stage, also object to such a sudden change. This may be why they prefer to stay in the sea during the cold wintry weather. It is true that grilse oc- 
casionally begin to run much earlier in some years than in others, but I have never heard of one being caught before April. I think the foregoing remarks sufficiently explain the reason why grilse differ from adult salmon in their habits on entering fresh water. Doubtless we might gather some information on this interesting subject by taking notes of the temperature of the water in various rivers year by year just at the time when grilse are running. Should it turn out to be a fact that they never attempt to leave the sea until the fresh water has risen in temperature to a certain height, we should have corroborative proof of the effect which the temperature of the water has on their movements generally.

\section{DO SALMON FEED IN FRESH WATER?}

IT is a very rare occurrence to find food in the stomach of a salmon, and therefore it is generally believed that salmon do not feed in fresh water. 
Dr. Francis Day, in a letter to The Field, in November, I885, says that "a salmon exists in fresh water on his own fat, which has been accumulated while feeding in salt water." But the writer did not bring forward any evidence to support that theory. I grant that a salmon falls off in condition from the day it leaves the sea, because there is but little fattening food in fresh water; but the process of deterioration is a gradual one, and although the fish lose their beautiful silvery appearance, and become more or less discoloured, they do not lose much in weight until their ova are in an advanced stage. I should say, therefore, that it is more probable that the ova of a salmon become developed by the nourishment they receive from its fat, than that the salmon itself exists upon it. Its fat disappears in proportion as the ova develops, and by the time it is ready to spawn, not a particle remains. It appears to me perfectly natural that this should be so. There can be no question as to salmon feeding in 1 This theory was believed in by the late Frank Buckland. 
fresh water, as they greedily tảke real and artificial spinning baits of all kinds, besides prawns and worms, to say nothing of flies natural and artificial. It cannot be supposed that they do so to gratify the angler's love of sport, or for their own amusement, or that they can find pleasure in disgorging what they have swallowed. They often greedily seize what they suppose is natural food, though it be attached to the coarsest tackle, and more than likely to scare every salmon from the pool. We know this to be a fact from every-day observation. Surely, then, they feed in fresh water on such natural food as they find, and I cannot make out why people think otherwise. Thousands of salmon have been caught in the sea. which must have only a very short time previously swallowed food. "What then becomes of the food? It could not have been digested at a moment's notice, and yet food has rarely been found in the stomach of these fish. It is absurd to imagine, as some people assert, that the digestive powers of salmon are so singularly active, 
that the food can be got rid of almost as quickly as it is swallowed. It is far more probable that on finding themselves in trouble they disgorge their food; indeed there are several authenticated instances of their having done so. This, therefore, would seem to be the only true solution of the problem.

\section{THE EFFECT OF TEMPERATURE ON} THE HABITS OF SALMON, AS REGARDS THEIR FEEDING.

Every salmon fisherman knows that the fish take flies or baits much more greedily in cold weather than in warm. I have frequently broken the ice on frozen pools in the north of Scotland and caught clean-run fish in them within a short time afterwards. I never expect to meet with a blank day in the coldest weather, if I know there are fish in the river; but salmon make a poor fight in very cold weather, and are often brought to bank without 
EFFECT OF TEMPERATURE ON SALMON. 105

having taken out a yard of line. When the temperature gets warm in July and August, the fish always become very sulky. This is generally the time of year when the temperature of the water in all our rivers is at its maximum height, when fish refuse the most tempting lures, and although the angler may have cast his flies in the most artistic manner over thousands of clean-run fish, he will as often as not go home with an empty creel. On one occasion, when fishing the Lyngdal in the South of Norway, down which river snow-water never flows after the beginning of June, my friend and I killed eleven fish one day in July, when the fish were plentiful, and the water in first-rate order; but during the following night the weather changed from temperate to very warm. The next day the thermometer stood at $84^{\circ}$ in the shade; the fish left off feeding, and we caught no more until the weather changed again and became colder. But although in hot weather, such as I have described, the temperature of the water will invariably become 
proportionately warm in rivers that are not snowfed, this is not the case in the rivers that are thus supplied, as the temperature of snow-water is so low, that it is very little modified. by atmospheric conditions on its passage to the sea. In Norway, and in the north of Scotland, it would appear that salmon are acclimatized to cold weather and snowwater. In Norway, in particular, there are rivers that are fed by snow during the whole of the summer months, when the salmon will take flies and baits quite freely. They will also do so in many rivers that are snow-fed in the north of Scotland during the spring months, whereas in the more southern rivers of the United Kingdom, a salmon fisherman will hardly think it worth his while wetting his line in snow-water.

There are many conditions of weather each having an effect on the appetite of salmon; an east wind at any time, particularly during the months of September and October, accompanied by a warm temperature and a hazy, blue atmosphere; 
a south wind; a rapid fall of barometer; a fog at any time; a still, muggy day with an overcast sky and a warm temperature, also have more or less effect in making salmon disinclined to feed. In an east wind, under the conditions I have described, the angler may just as well stay at home. He may possibly get a fish or two to rise the first thing in the morning or late in the evening, but he will waste his time fishing during the day. A frosty night in autumn followed by a bright sunny day, sharpens the appetite of a salmon in a marvellous manner. The best day's fishing I ever had under such conditions as those was on the Tay, in the month of September. The water was in firstrate order, and, for the information of my brother anglers, I may just say that the fly I used had a silver body. I have always noticed that during the autumn months, as well, indeed, as at any other season, of the year, salmon are far more inclined to feed in cold weather than in warm. The autumn of I 886 was unusually mild, when I was fishing the 
Stanley water, on the Tay. On several occasions, when the water was in first-rate order and any amount of fresh-run fish were in the pools, I hardly had a rise. One day I could not stir a fin with a fly, nor could I induce a single fish to take a phantom minnow or a prawn. On that particular day only one or two fish were killed by six fishermen on the Stobhall water, known to be the cream of the Tay. The day was still and muggy, gossamers were floating in the air, and a foggy, blue mist hung over the water's surface. On the other hand, the autumn of I 885 was cold, and the fish took greedily up to the last day of the season. On one occasion I even felt cold enough to light a fire at lunch-time, and yet I had plenty of sport, from morning till night.

Salmon are less inclined to take a fly in some rivers than in others. Here and there they take either flies or baits greedily, whilst in some localities baits are preferred. Again, there are rivers in which flies alone are taken; and however much you may 
EFFECT OF TEMPERATURE ON SALMON. 109

persevere with baits, natural or artificial, you do not succeed. The Trent is a river in which salmon rarely rise at flies. This is not because the water is too deep, as many of the streams are of a depth suitable for raising fish. Salmon in the Trent are taken with artificial bait, but why they decline to take a fly it is difficult to understand. The Usk is the freest rising river I ever fished-even in July and August, when salmon are sulky in almost every other river-and when the water is in ply, no one need despair of getting sport. But with an east wind in autumn, and such conditions as those mentioned, even on this free-rising river the sport is spoilt, no matter how plentiful the fish may be.

In his book on "Salmon Problems," Mr. Willis Bund states that "any salmon fisherman would admit that salmon travel more by night than by day." Admitting that a great proportion of fish that ascend our rivers travel by night, I have sometimes seen them travel in very low water when I have been fishing. Mr. Bund states, however, that 
unless there is a fresh in the river, salmon do not travel in the day-time, and goes on to ask whether it may not be that fish feed by night and not by day. As far as my experience teaches me, salmon feed more by day than by night. Moreover, early in the spring they appear more inclined to feed from about Io a.m. to I or I.3O p.m., and again from about 3.30 p.m. to dusk than at any other period of the day; or should there be a hard frost, from 3 p.m. to dusk. In frosty weather it is not worth while wetting a line early in the day. Later in the spring and in the summer months when the weather becomes warm and bright, salmon feed much earlier in the morning and later in the evening. I do not know, however, that very early hours are the best for fishing, as I have never had very good sport before about 8 a.m. In the north of Scotland and Norway, at the time of year when you can see to read all night, salmon are always more or less on the feed during the twentyfour hours, but certainly not as well at night as 
in day-time. I noticed this particularly when fishing the Namsen, in Norway, where I caught by far the largest proportion of fish between 8 a.m. and I.30 p.m. When fishing the Mols River, further north within the Arctic circle, where the sun never sets in summer, I noticed that the fish were far less inclined to feed during the small hours of the morning than at any other time. They took fairly well up to i 2 o'clock, and afterwards appeared disinclined to feed for several hours. I have noticed that salmon are more hungry in the spring of the year soon after sunset, and continue to feed freely until it is too dark to change one's fly. They then stop feeding all of a sudden, and in my belief do not begin again until about nine or ten in the following morning, provided always there is no frost. Taking the season through, I have killed far more salmon from this time up to I.30 p.m. than during any other period of the day, and I do not think I am wrong in asserting that the fish feed more by day than by night, except perhaps in the very height of summer. 
I shall never forget a sight I witnessed on the Boyne, in May, I885, by the mill weir at Dunmore. The water was dead low at the time, and also very clear; there was only just enough of it in places to enable salmon to pass over the weir, and yet the fish were moving about the whole day. Every time I passed the weir backwards and forwards to the pools, I saw fish going over. They were coming up the shallows below the fall with their backs out of water, and this went on for two days in succession, during which time thousands must have passed up. Shortly afterwards, $\mathrm{Mr}$. Fitzherbert and his party (three rods and a cross line) killed fifty-six fish in one day's outing, twentysix of which number fell to Mr. Fitzherbert's own rod. This is the only time I ever saw salmon travel in large numbers in low water in the day-time, though I have often seen them travelling singly and in pairs under such circumstances. A high wind induces them to travel in the day-time, however low the water may be. I have seen a reach of 
dead water well stocked in the morning, utterly deserted at night, and fail from being exposed to a high wind. However much inclined salmon may be to enter fresh water, a high wind has great effect on their movements. If the wind blows to the shore, they go out into the sea, and do not approach the estuary again until it changes. On the other hand, should the wind blow from the shore, the fish come in with the tide even when the river itself is dead low.

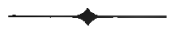 \\ PARASITES.}

SALMON are infested with three different kinds of parasites; one kind adhere to the gills, and anglers give it the name of "Maggot": the others to the body, and are commonly called sea and freshwater lice. The presence of maggots is generally considered as a proof that the fish are unclean; and in most instances justly so, but not always, for it is 
not a very uncommon occurrence to find parasites in the gills of clean fish. I have on several occasions caught salmon with sea lice on them as well as maggots in their gills. This has been in the spring, when the fish are unmistakably clean; and I have also caught them in spring with maggots in their gills and without sea lice on them, when their flesh was quite equal in richness to any I ever tasted. Perhaps, innocently enough, many a good salmon has been returned to the river which should have had a berth in the captor's creel. Maggots are frequently found in the gills of bull trout caught in the tideway by nets. I do not know why they are more prevalent among bull trout than salmon, but such is the case. With regard to parasites found on the body of salmon, Mr. Willis Bund, in "Salmon Problems," says, "That many ignorant persons mistake fresh-water for sea lice." Quite so. But I would remark, that salmon are not attacked by fresh-water lice until they have been some time in the river; and it is principally in very low water, and during the hottest weather 
when the fish are indisposed, that they are thus infested. Any salmon fisherman should at once detect the difference between fresh-water parasites and sea lice, for they are as different as chalk and cheese. It is generally believed that sea lice can live no more than twenty-four hours at the utmost in fresh water. But there have been instances of salmon being caught forty miles up the river with sea lice upon them. If so, and if the theory be correct, they must have travelled these forty miles in twenty-four hours. That appears to me impossible. I need not repeat my remarks on the rate at which salmon travel. I will only say that, in my belief, sea lice live in fresh water a much longer time than twenty-four hours. Fish infested with sea lice have been killed at Grandtully, on the Tay, and at Meggernie Castle, on the Lyon, a tributary of the Tay. The former locality is at least forty miles, and the latter eighty miles above the tideway at Perth. I did not ascertain the exact date these fish were caught ; but assuming that they had travelled at their maximum pace in 
summer, then the parasites must have lived in fresh water about forty and sixty hours respectively. $\mathrm{On}$ one occasion I caught a salmon with two unmistakable sea lice on it, in the month of June, about half a mile below Abergeldie Castle on the Dee, in Aberdeenshire. That must be quite sixty miles by the river from the tideway at Aberdeen. Now the streams of the Dee are, if anything, more rapid than those of the Tay, and therefore it may be presumed that this fish took a longer time to travel the distance; consequently the lice must have lived in fresh water sixty hours, and in all probability longer. It is, however, possible that in summer, sea lice live longer in rivers when the water is warmer than at any other time of the year. It could easily be ascertained how long sea lice can live in fresh water in different temperatures, by keeping fish in confinement in the boxes at a weir just above the tideway in a river into which fish run during spring, summer, and autumn. The cages on the weir in the Galway river would be very suitable for making such an 
experiment, and by comparing notes, we might also obtain some further light as to the rate at which fish travel.

\section{AUTUMN AND WINTER EMIGRATION OF SMOLTS.}

Mr. Bund, in his excellent work to which I have alluded, gives us one unmistakable instance of an autumn run of smolts, which took their departure from the Severn in December, 1884 . Since reading the account, I have made constant inquiries, and not long since was successful in obtaining some reliable information on the subject. When fishing at Galway, in September, I887, I met with Nicholas Browne, who for the greater part of his life has been in charge of the rod-fishing there. In the course of conversation he informed me that smolts made their way to the sea every winter from 
that river, and that as many as twenty had been caught in one night in the eel traps. To satisfy me of their presence at that time (the latter end of September), he put up a trout rod, and soon caught a small fish, not a brown trout parr, but an unmistakable salmon parr, which, although it had none of the silvery appearance of a smolt, upon close inspectioe gave me the idea that the process of donning its bathing dress, as a well-known author not inappropriately puts it, had already commenced. Browne informed me that, when the fishing opened in February, all these little fish had disappeared, and that none of them were seen again until near the time of their spring voyage. He remarked that the number in winter was very limited in comparison with that in spring. I have since received a consignment of fish which were caught in the eel-traps in the Galway river in December, 1887 , and on forwarding them to Dr. Gunther, he pronounced them to be samlets.

We have, therefore, evidence amounting to abso- 
lute proof, that smolts make their way to the salt water at other times of the year than in the spring. It must not be assumed that the two instances of the late run of smolts referred to are mere individual exceptions to the general habits of these fish, though it is certainly surprising that we get so little information in regard to their habits in other rivers. On that point, howeyer, there is a good reason forthcoming by way of explanation. Taking it for granted that smolts are frequently caught in autumn and winter, the very fact of being found in possession of them subjecting the offender to a heavy penalty fully accounts for their capture having been kept a secret. Moreover, during the close season, when all kind of fishing is prohibited, the banks of the rivers are deserted except by water bailiffs and poachers. The former take little interest except in the duties they are paid to perform, and even if they were on the look-out, no fish would be seen rising during the cold winter months. Thus although the rivers might be full of smolts, the 
watchers may walk the river-banks for months without seeing a single fish show itself; and thousands of smolts may have passed them on their way to sea year after year in autumn and winter absolutely unseen by any one. In fact, had it not been proved by the eel-traps, the presence of these fish at Galway would probably have remained unknown for years. But in spite of the conclusive evidence of the winter emigrations from two rivers, it cannot be taken for granted that such is the general habit elsewhere. Smolts bred in the Stormontfield, Howietown and other fish-ponds have never as yet been known to evince the least desire to go to sea before the spring months. This of itself tends to upset the autumn or winter theory, but if I am rightly informed, the smolts in ponds mentioned above are bred exclusively from the ova of autumn salmon. After hatching, the fry take a certain time to develop themselves into parr, and do not reach the smolt stage until the spring twelve months after the date of their birth. It 
is then that they assume their silvery coat before going to sea. Some of them, however, prefer staying in the fresh water, and do not leave the ponds until the spring following. Therefore we have strong evidence that smolts which go to sea in autumn or winter are not connected with those hatched out from autumn spawners. But there are fish which spawn all through January and February, or two months later than those which spawn in November, whose ova are available for a future supply, although perhaps in limited number. A cold temperature, we are told, retards the hatching of ova, and as the temperature of river water is, as a rule, lower early in the spring than in November and December, January and February, the ova take longer to hatch then than at other times. It may therefore well be, that parr bred from January and February ova are not ready to go to sea as smolts until five or six months later than those bred from November ova. And if so, we have at once a reason for the winter being chosen for the voyage. 
Again, I do not see why the winter may not be chosen for the emigration of the hardier fish bred in the main river, whilst those bred artificially prefer the spring. But to ascertain whether this is a general habit or not, we have only to mark the fish in order to decide once and for all. I am inclined to believe that winter smolts are not bred from ova spawned in November, and therefore a considerable number of parr bred from ova of late spawners should be marked and turned out into the breeding ponds along with those bred from ova of the November fish, besides turning out a lot into the main river. We should then ascertain whether the marked fish in the ponds evinced any desire, by restless movement round the blocked exits or otherwise, to get to sea in winter; unless, of course, it be contended that the fact of their being in confinement would so alter their nature as to take away, or at any rate to retard, their desire for departing. Some of the smolts which were turned into the river would most probably be caught 
in the eel-traps, on making their way to the sea, and for the production of these I would offer a special reward. We should derive considerable benefit from ascertaining the exact habits of autumn and winter smolts; besides knowing whether they are bred from late spawning fish, in which case they could be enormously increased in numbers by artificial means. The probable result of this would be a large increase of grilse in April and May. Naturally those smolts that reached the sea in winter would have developed into grilse by these months, whilst a proportion of them following their natural instinct would come again into fresh water. In many rivers, I have noticed that grilse of the first run are very small, averaging no more than 3 lbs. to $3 \frac{1}{2}$ lbs. in weight. It is hardly possible that these small grilse were the very smolts that went to sea in April and May of the previous year, as they would surely have attained a weight of at least 5 lbs. or 6 lbs., and so it would appear that they belong to a family that reached salt water in the winter. 


\section{WHAT ARE UNCLEAN AND UN- SEASONABLE SALMON?}

UndoubtedLy, salmon are unclean from the time their ova have reached that stage at which they are commonly called gravid fish or baggits, to the time when they return to sea as spent fish after spawning. There are, however, different opinions as to the true meaning of "unseasonable" salmon.

The word "unseasonable" is not uncommonly interpreted as applicable to unclean salmon only, which, not being fit for food, are, therefore, out of season for the table; that is to say, every fish unfit to be eaten at table is regarded as an unseasonable salmon, and vice versât as regards a seasonable salmon. But this could not have been the meaning intended to be given to the word " unseasonable" by those who framed our Fishery laws; for, assuming that it is unlawful to kill or 
have in possession, an unseasonable salmon, and that it is lawful to kill or have in possession a seasonable salmon, if the word "seasonable" is applicable to clean salmon only, then clean salmon could be killed all the year round with impunity. But the law imposes a heavy penalty for killing or having in possession any salmon during the annual close season; therefore, it should be held, that the word "unseasonable" is applicable under certain circumstances to clean, as well as to unclean salmon, and in all probability was inserted in the Fisheries Act, in addition to, or rather in conjunction with, the word "unclean," with the especial intention of protecting clean salmon during the fence months. The selection of the word, however, was a most unfortunate one, and, to say the least of it, is very misleading; for, if it is unlawful to kill clean salmon during the fence months for the reason that they are unseasonable-that is to say, if the sole ground of prohibition is to be the period of the year in which they are taken, and not the condition in 
which they are found-it should follow, that it is lawful to kill gravid and spent fish during the open season, because it must be held that they are seasonable.

The following cases in which the Sheriff of the Selkirkshire Court appears to have taken this view, are reported in the Field of December Ist, 1888 :-

"BACK-END SALMON.-A case that will be read with interest by late salmon anglers was heard on Wednesday in the Selkirkshire Sheriff's Court. There were two cases in which certain persons were charged with having had 'unseasonable' salmon in their possession. In one case the police-constable who seized the fish, stated he could not testify as to whether it was 'clean" or 'unclean ;' and the inspector of police, by whom the salmon had been examined, said it was a female fish partly spawned. A leading witness in the other case deponed that he never knew of an angler returning any kind of salmon to the river at this season; he took all he got. However, it was different in the spring. Both cases were dismissed by the sheriff. Had a conviction been secured in any of the cases referred to, it would have caused some uneasiness amongst salmon anglers. The practice during the back-end season is to take all fish caught by legal means, no matter how near the spawning point they may be. The fact, however, that persons should have been proceeded against for having in their possession unseasonable fish at this time of the year, proves that the law on the subject requires elucidation." 
If the word "unclean" had been inserted in the indictment, I do not see how a conviction could have been avoided; but, in the absence of that word, if the decision of the Sheriff of the Selkirkshire Court is to be established as a precedent, and the autumn salmon that are almost in the act of spawning, are allowed to be killed by anglers with impunity, with what justice can any person be convicted in future, for killing a spent or gravid salmon during the spring months? Many a poor man has been fined and sent to prison for killing gravid and spent fish in the spring of the year, whereas any one may gaff and kill gravid fish at the back end of the season, and no notice is taken of it.

Which of the two proceedings, may I ask, is the most injurious to a future supply? Anglers killing spent fish which devour thousands of smolts in their passage to sea during the spring months, as well as a few gravid fish whose ova are almost worthless for breeding purposes; or, the wholesale 
slaughter of gravid fish all through the back end of the season-the very fish we depend upon for the occupation of the spawning beds during the forthcoming spawning season? To convict in one case and not in the other is most unjust. The following is a report of another case in which the question was raised by defendants' solicitor as to the interpretation of the word "unseasonable " :-

A Nice Point in the Salmon Fishery Law.-The county magistrates, sitting at Barnstaple Police Court, were on Wednesday called on to decide a somewhat novel point, raised in the interpretation of the Salmon Fishery Acts. Five fishermen, of Barnstaple, were summoned for having taken an unseasonable salmon on April 24th, at Heanton Punchardon, the Taw and Torridge Fishery Commissioners being the prosecutors. It appears that the defendants were seen to catch a salmon in their net on April 24th, during the close season, and put it into a bag, but on finding they were observed they threw it back into the river. Mr. Bencraft, in defence, raised this point-that, under the section of the Act, it rested with the prosecution to show that the fish was an unclean one, and this they had failed to do. The Act did not make it an offence to be in possession of a clean fish at any time, but it was an offence to have an "unseasonable" salmon during the close time. The word " unseasonable " meant "unclean," which was the ordinary meaning of the word, and it did not in this Act mean a salmon which was clean and caught during a close season. The defendants' solicitor then went on 
to defend the case on the facts. He denied that any fish was caught, and called a man who was present to support this contention. The prosecuting solicitor, in reply on the case, contended that an unseasonable salmon was any salmon caught during the close season.-The Chairman (Sir A. Chichester) said the Bench had decided against Mr. Bencraft on the point of law. They also believed the defendants to be guilty, and they would be fined Ios., the value of the fish, and $2 l$. each and costs, or in default one month's imprisonment. A fortnight was allowed for payment.

In this case, the magistrates very properly convicted the offenders, but who could have blamed them, if, owing to the present uncertainty as to the true interpretation of the word "unseasonable" in the Fisheries Act, they had decided otherwise? Year after year I have read accounts of failures in prosecutions against persons for killing or having in possession unseasonable salmon, but the cases I have cited will of themselves be amply sufficient to show how necessary it is that the wording of the Act as regards unclean and unseasonable salmon should be amended. By rights angling for salmon should cease after the Ist of October, but as this would be a great hardship on such anglers as are solely de- 
pendent 'on fish which run up during the autumn months for their sport, it is very unlikely that angling after that date will ever be put a stop to. It would be far better that it should be made lawful for anglers to capture gravid fish at any time during the open season, than to allow the provisions in the Fisheries Act against doing so to remain and not put them in force. It is my opinion that the words "unclean" and "unseasonable" should be erased from the Statute Book, and that it would simplify matters if, instead thereof, it should be enacted that it would be unlawful to kill or have in possession any salmon during the annual close season; but that the capture of any salmon other than spent fish by anglers fishing fairly with rod and line during the open season should be allowed; and that any person convicted of killing gravid fish during the spring months, or at the back end of the season, after the annual close time for nets has commenced, by any means other than with the rod and line, or by snatching salmon with rod and line at any time during the open 
season, should be subject to a heavy penalty. I think, even in the case of spent fish, which invariably make sad havoc among smolts, and are nothing more or less than fresh-water sharks, that it would be wise to allow anglers to capture them after a certain date, say the $25^{\text {th }}$ of April. If these suggestions should meet with favourable consideration, and my views adopted, magistrates would have a very plain and easy duty to perform when offenders are brought before them, and there would be less risk of the ends of justice being defeated than at present. The consequence would be that we should hear no more of the question touching unclean and unseasonable salmon, of which, I feel certain, that anglers in general, and magistrates in particular, are heartily sick.

\section{WELL-MENDED KELTS.}

WhAT is a well-mended kelt? is a question I have often heard asked; but it appears that no one has as 
yet been able to give a satisfactory answer. I do not pretend to be able to do so myself, but I will give my opinion for what it is worth. A wellmended kelt is, as a Scotchman would say, "just a well-mended kelt," or, in other words, a spent salmon which has grown fat in fresh water on smolts on their way to the sea. These fish attain such a good condition, that even experienced salmon-fishers are sometimes puzzled at first sight to distinguish them from clean fish. An ordinary spent fish can be identified at once, be it never so bright-looking and silvery. A big head, out of all proportion to its body, a tucked-up belly and a large and protruding vent are outward and visible signs which cannot be mistaken, maggots also will invariably be found in its gills; but as insects, apparently similar to them, which have been proved to be marine parasites, are occasionally seen adhering to the gills of bona fide clean salmon, and sea-lice adhering to their bodies at the same time, I should not attach much importance to this as a test. It is, however, as I 
have before mentioned, not very easy to identify a well-mended kelt, though an experienced salmonfisherman does not find much difficulty in doing so. A close examination of its vent should decide the matter, and, in my opinion, that is a test we may all thoroughly rely upon. The vent of a fresh, clean fish is very small, and in some instances, I may say, barely visible; whereas that of a well-mended kelt, although not so large or protruding as that of a recently spent fish, bears unmistakable signs that its possessor has passed a certain period of the previous winter months on the spawning beds. Should any one be in doubt, let him place a fish, which by common consent is supposed to be a wellmended kelt, alongside of a bona fide clean fish. The well-mended fish may be silvery, and appear to be in as good condition as the clean fish, but there is much difference in the appearance of the two, which, putting aside the infallible test of the vent, must be plainly visible to the practised eye. There is always a difference seen in the brightness of the 
scales in the spent fish when compared with those of the clean one, whilst the prismatic hues-so beautifully developed on the back of the latterare entirely absent on the former fish. The question may well be asked, How do we account for spent fish remaining behind in fresh water, when nine-tenths and more of the migratory body to which they belong have gone to sea? The best answer to that would be to put another question, i.e. As a proportion of both smolts in fresh water, and clean fish in the sea, remain behind after the migration of their co-ævals, is it very surprising that some of the spent fish continue longer in fresh water than others, and so exhibit the like habit?

How long they remain behind it is impossible to tell. Salmon anglers often catch ugly-looking fish towards the close of the season, which perhaps are nothing but well-mended kelts. Those fish, in common with the majority of others at that season of the year, lose the condition they were in a few months previously; and whether they develop. 
ova or not, or when they return to salt water, we have yet to ascertain. It is stated that landlocked salmon develop eggs; it may therefore be that spent fish which remain in fresh water during the summer months do the same, and occupy a berth in the spawning ground, and return to sea during the forthcoming spring months with the fish that have spawned with them. This problem might be solved by marking spent fish when in the condition of wellmended kelts; but I really do not think that the game would be worth the candle. It is notorious that these fish devour a large number of small fry during 'the summer months, and so when caught should be destroyed. And here, although it may be thought that the remarks I am about to make are foreign to the subject on which I am just now discussing, I trust I may be excused if I take the opportunity now offered of making an appeal in behalf of spent fish, which, I regret to say, are looked upon by not a few salmon fishermen as mere vermin, and treated in some instances with unnecessary cruelty. They are 
often gaffed without a thought as to whether they are clean fish or kelts, the hook is ruthlessly torn or cut out of their mouths, or from whatever part of their body it may be fixed in, and the poor things, bleeding and mutilated, thrown into the river with a kick and a flourish of adjectives. What chance, may I ask, has a spent fish thus ill-treated of living to return to the river as a clean fish? It is doubtless very annoying and trying to the patience to fish the whole day and land only spent fish; but the angler whose temper is so tried should bear in mind that these very fish which they think are such a nuisance, and often tear their pet flies to pieces, have been clean fish the previous year, and have run the risk like many other salmon of being captured by him. It may be that he has had more than one old kelt at the end of his line, which, having gallantly fought for its life, has yet escaped. Moreover, the very kelts anglers so despise and ill-use, may, if tenderly handled and returned to the river with the least possible delay, live and become their legitimate prey as clean fish 
afterwards. No sportsman should ever be guilty of ill-treating spent fish, and my remarks are intended only for those who thoughtlessly, and not with wanton cruelty, are in the habit of so doing. It is my belief that spent fish which meet with even the more considerate treatment seldom recover, whilst the gaffed ones incur a certain and lingering death. The use of the gaff, therefore, should be prohibited until the spent fish have left the river.

\section{AGE AND GROWTH OF SALMON.}

These questions are so mixed up with one another, that in the following remarks I make no apology for treating them as one.

If I may refer to "Salmon Problems" again, Mr. Bund wants to know "What is the age of a 4olb. salmon?" The question is certainly one which it is impossible to answer satisfactorily.

If a salmon of $40 \mathrm{lbs}$. weight were caught and 
identified as one that had been marked when young, we could then say with some truth what the age of this actual fish was. But we know that there is a great disparity as regards the rate at which salmon grow. Some rivers, such as the Tay, in which salmon of 40 lbs. weight are not uncommon, breed fish which have been known to scale as high as 7olbs., whilst very few salmon in many rivers would attain the weight of $40 \mathrm{lbs}$., if. they live to the age of Methuselah. The following remarks on "Salmon," given by Mr. Cholmondeley Pennell, in the Badminton Library, page $14 \mathrm{I}$, in reference to the smolts that were marked at the Stormontfield ponds on their way to sea, and captured on their return to fresh water as grilse the same year, illustrates the disparity in regard to the rate at which the salmon of the same river grow :-

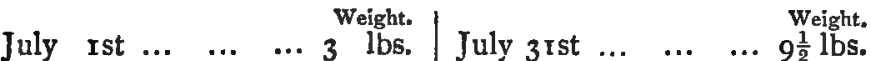

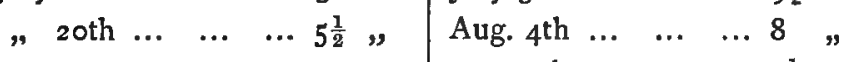

$$
\begin{aligned}
& \begin{array}{lllllll}
\eta & 2 \text { Ist } & \ldots & \ldots & \ldots & 5 & \eta \\
, & 30 t h & \ldots & \ldots & \ldots & 7^{\frac{1}{2}} & \|
\end{array}
\end{aligned}
$$


There is also a well-authenticated instance of a smolt that was marked on its way to the sea, and that, when taken the next year on its return from salt water, weighed $20 \mathrm{lbs}$. It cannot for one moment be taken for granted that all salmon grow at such a rate ; but had this little fish, which was marked when a smolt, continued to grow with the rapidity of its grilse year, it would have attained a weight of 40 lbs. under four years from the date of its birth. Of course this estimate is made without taking into consideration that the fish had spawned, in which case it would take another year before it could put in an appearance as a $40 \mathrm{lb}$. fish. It is very evident that we could only in isolated cases ascertain the age of salmon of such a heavy weight as 40 lbs., and when we consider the infinitesimal number of smolts that are marked, and also the very small proportion of salmon that ever attain a weight of 40 lbs., the chances of ascertaining the age of even marked fish of such a weight are very small indeed, whilst to ascertain or even give an ap- 
proximate estimate of the age of salmon of $40 \mathrm{lbs}$. weight in general, is almost impossible. The age, however, of individual fish of lighter weights can be, and has been ascertained, notably in the case of the marked smolt which was caught the next year, weighing $20 \mathrm{lbs}$.; but the fact alluded to about the disparity in the rate of growth of the grilse mentioned by Mr. Cholmondeley Pennell, will show that it would be impossible to form a correct general estimate of the age even of grilse of any given weight. We have ample proof of the astonishing rate at which immature salmon grow, but who can tell whether they continue to grow so rapidly after they have reached the adult stage. Human beings, beasts, and birds continue to grow up to a certain age, and no longer. Is it then unreasonable to assume that in like manner salmon grow very little, or not at all, after they have reached a certain stage of their existence? Again, as regards disparity in their growth. Is it not probable that those fish which have access to 
the same feeding-grounds, may, like human beings, beasts, and other living things in creation, be differently constituted, and that some will grow fat in a far less time than others. It is my belief that this accounts for the disparity in the weight of immature fish of the same age, which are natives of the same river. But why salmon in some rivers attain a far heavier average weight than they do in other rivers is a different thing altogether, and can only be accounted for in the way I have before described, viz. that the feeding-grounds in the sea, appertaining to each river, vary in richness of food, as do pastures on land; so that salmon having access to the richer feeding-grounds grow to a far heavier average weight than those which have access only to poorer feeding-grounds. There appears to be a difference of opinion in the minds of high authorities as to the nature of the food salmon get in the sea; some say that they feed on shrimps, others on different kinds of fishes ; but as any kind of food is seldom found in the 
stomach of a salmon, my opinion is that no one knows, or ever will know, what these. fish feed on in the sea, nor do I think it is a question we need trouble ourselves much about.

\section{SAPROLEGNIA FERAX, COMMONLY}

\section{CALLED SALMON DISEASE.}

THIs is a question I approach with great diffidence. It is one which has occupied the attention of scientists for many years, who, although they have made certain discoveries, which may eventually lead to satisfactory results, have not as yet been able to explain the nature and origin of this devastating disease, or to point out any means for its prevention and cure.

As I have said, I am no scientist, neither do I profess to be able to make any addition to the present limited stock of original data on this question; nevertheless, from what I have read, taken in conjunc- 
SAPROLEGNIA FERAX, SALMON DISEASE. I43 tion with the result of personal observation and inquiries made at the river-side, I have formed certain opinions which I venture to offer for general consideration.

In the first place, although it may seem to be of minor importance, the use of the term "Salmon disease," as an alias for "Saprolegnia," is misleading. For it is well known that not alone salmon, but also coarse fish and even minnows are often affected with this disease. If it could be proved that saprolegnia always originated with the salmon and was communicated by it to other kinds of fish, there would be some justification for the present use of the term, but until this proof has been supplied it would be well to avoid what is really a mischievous misnomer.

Although it is not known when this disease first made its appearance, all seem to agree that it is of long standing. In my younger days, very little was heard about it, and I think it may be assumed that the mortality among fish affected with saprolegnia in those days was very slight in comparison to what it 
has been of late years. Professor Huxley, late Inspector of Salmon Fisheries for England and Wales,

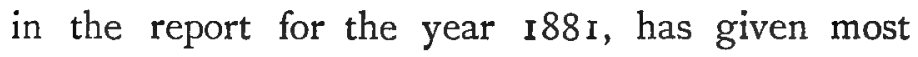
interesting information on the question of the socalled salmon disease. He states that, "It was originally brought to notice by a remarkable outbreak in the spring and autumn of 1877 in two rivers, the Nith and the Esk flowing into the Solway Firth," and he goes on to say, "It soon spread to the Eden and other adjoining rivers. In the spring of 1879 , it was observed in the Tweed, when it rapidly became yery serious, and in 1880 , when a commission was appointed to investigate it, it had extended to the Annan, the Eden, the Cree and the Dee, all flowing into the Solway Firth; to the Doon and the Ayr in Ayrshire, to the Derwent in Cumberland, the Lune in Lancashire, and to the Tweed. Since then the disease has broken out in the Seont, the Ogwen, and the Conway in North Wales, and in the Tay, and North Esk in Scotland." There have been also serious outbreaks of the disease in the Usk in Mon- 
SAPROLEGNIA FERAX, SALMON DISEASE. 145 mouthshire. I cannot fix the date on which it first made its appearance in the Usk, but as this river is not mentioned in the report of $188 \mathrm{I}$, it must presumably have been after the date of the report.

As saprolegnia is an infectious or contagious disease, it is not surprising that it spread in the first instance to rivers in the Solway Firth, adjoining the -Esk and the Nith, but it is difficult to account for its appearance in Scotch rivers on the east coast, and also in the Welsh rivers, and not in rivers intervening. The Ribble in Lancashire, adjoining the Lune; the Dovey, the Towey, and Teifi on the Welsh coast, and all the rivers from the Doon in Ayrshire round the north coast of Scotland, as far as the North Esk, are all intervening rivers which appear to have been free from disease, but the most unaccountable

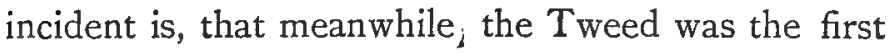
river in which it made its appearance after the outbreak in the Nith and the Esk in the Solway Firth. No one is able to say where migratory fish go to during their sojourn in the sea; there is a well- 
authenticated instance of a bull-trout, which was marked in the Tweed, having been caught by the nets on the coast of Norfolk, and for aught we know salmon may travel as far away from their native rivers as mid-ocean. I can affirm of my own knowledge, that there are a certain number of diseased fish in the sea, and as there is a prima facie evidence that diseased fish belonging to one river can communicate the disease to fish belonging to other rivers, it is just possible that some of the diseased Solway Firth fish came across some Tweed fish during their rambles in the sea, which might thus account for the sudden outbreak of saprolegnia in the Tweed; but the most probable theory to account for its appearance in the Tweed, as well as in other rivers, is that the seeds of saprolegnia lie dormant in the bed of the river which, under certain unknown conditions, germinate and produce a fungus, from which spores get detached, one of which, according to Professor Huxley, is sufficient to kill any salmon it comes in contact with, provided it adheres and germinates, 
SAPROLEGNIA FERAX, SALMON DISEASE. $\mathbf{1}_{47}$ boring its way through the epidermis or outer skin, into the derma or true skin of the fish. But why the disease should have lain dormant prior to 1877 , to break out so suddenly during that year, is a problem that has yet to be solved.

Many theories have been propounded from time to time to account for the origin of saprolegnia: the most popular, and I think, the most plausible, are two, one ascribing it to overcrowding, the other to pollution.

It ought not to be a matter for surprise, if in any river in which the number of fish should exceed the natural capacity of maintenance, epidemic disease of some kind should break out; but unfortunately the provisions of the Salmon Fisheries Act have not brought about such a state of things as the overcrowding of many of our rivers with salmon. Fish do certainly occasionally overcrowd in some rivers in low water below weirs and other obstructions which they are unable to surmount, and in deep pools and holes, when the water has got too low for 
them to remain in their stands in the shallower parts of a river, as they also do in the lower spawning grounds when there is not enough water to enable them to reach their spawning grounds higher up the river. Salmon die in considerable numbers of some disease in the upper reaches of the Aberdeenshire Dee, during the summer months, which may be due to the overcrowding of the fish in the deep holes when the water is low. I myself saw numbers of fish dead and dying when fishing the Dee between Balmoral and Ballater on one occasion, during the month of June, and my attendant informed me that it was almost a yearly occurrence; but, inasmuch as we do not hear that saprolegnia has ever broken out in the Aberdeenshire Dee, we may safely assume that these fish were affected with some other disease. Again, salmon are often so overcrowded in the Galway river, Ireland, in that part immediately below the regulating weir, that in many places the bed of the river is literally black with them, or as the Irish say, paved with them. They often remain in the 
same position for weeks together, and yet saprolegnia has never made its appearance in the Galway river. On making inquiries I ascertained that a disease somewhat similar in appearance, as described to me, broke out on one or two occasions during summer, when the water was very low, but no fish died from it, and it soon disappeared.

One significant fact in connection with saprolegnia seems to have escaped general attention. There is neither report nor record of the occurrence of this disease in Ireland. The cause of this exemption should prove an interesting problem for scientists. Independently of this, however, there is what appears to me to be an unanswerable argument against the theory that saprolegnia is originally due to overcrowding, viz. that it sometimes breaks out in rivers in which salmon are scarce, and in which it is hardly possible under any circumstances that the pools could be overcrowded with salmon.

Pollutions of all kinds are more or less injurious to fish; some contain the most deadly poison, and 
others, if not discharged into rivers in excessive quantities are, comparatively speaking, harmless. Sewage matter, for instance, is of a nature the least injurious, and my opinion is based on the fact that the biggest trout, in the finest condition, are to be found at a point directly below where sewage is discharged into a river. Refuse from tin, chemical, and gas works, washings from lead-mines and flax water, are all fatal to fish life, if the dose is strong enough; but it appears that what is enough to kill small and immature fish, is not enough to prove fatal to adult salmon. Not many years ago, when visiting the banks of the Dovey in North Wales, at Machynlleth, I noticed on a certain Saturday several small sewin (sea-trout) being carried down the river, apparently dying. On my asking a local professional what ailed these fish, he informed me that every Saturday washings from the lead-mines situated a little distance above, which had accumulated during the week, were let go into the river, killing most of the smaller fish, but producing no more apparent effect on the salmon 
than that of making them sulky and refusing to take the fly or any kind of bait. But, however fatal to fish life poisonous pollutions may be, this does not prove that saprolegnia is due to any of these agencies. A gentleman well up in chemistry, with whon I had a conversation not long ago on this subject, on my making the suggestion that the poisonous solutions used nowadays for dipping sheep which are drained off the land into a river might be a factor in the mischief, made the remark, "On the contrary, poisonous matter that would be fatal to fish life would in all probability destroy the fungus with which the fish are affected;" and it is quite possible that this theory may hold good as regards all pollutions of a poisonous nature. As remedies, however, such poisonous agents would be worse than the disease.

But putting aside the effect that pollutions of all kinds may have on fish, the question is, "Is saprolegnia due to any of these agencies?" The fact that this disease sometimes appears in rivers, which 
as far as can be ascertained, are practically unpolluted, would justify an answer in the negative. But before coming to such a conclusion, we may carefully study what is stated by Professor Huxley (the only source I know of for trustworthy information on the question of the disease), in the report of the Inspectors of Salmon Fisheries before alluded to. For the information of any of my readers who may not have perused this report, I quote as follows, from pages 26 and 27 :-

"A factory for making spirits from turnips was established near Schweidnitz, in Silesia, and the refuse was poured into an affluent of the river Weistritz, which runs by Schweidnitz. The result was such a prodigious growth of Leptomitus, that the fungus covered some I0,000 square feet at the bottom of the stream, with a thick white layer, compared to sheep's fleeces, choked up the pipes, and rendered the water of the town undrinkable.

"Scattered hyphæ of this Leptomitus may sometimes be found among those of saprolegnia, growing 

on fresh-water fishes, and the two forms are altogether so similar, that conditions analogous to these which stimulate the growth of the one may be assumed to favour that of the other.

"Brefeld has pointed out that there is no better medium for the culture of fungi of all sorts, than an infusion of dung.

"Land under high cultivation undoubtedly supplies the waters in its neighbourhood with something that nearly answers to an infusion of dung; and this must be taken into account in discussing the possible factors of salmon disease.

"Again, it is known, with respect to many of the common moulds such as Pencillium and Mucor which are habitually saprophytes (that is to say live on decaying organic matter as saprolegnia does), that they flourish in certain artificial solutions containing salts of ammonia.

"It is quite possible, though whether the fact is so will have to be experimentally determined, that saprolegnia is capable of living under the same conditions. 
"Fungi are also extremely sensitive to slight differences in the acidity or alkalinity of water, so that even apparently insignificant changes in this respect may come into play as secondary conditions of salmon disease.

"Hence, although there is not the slightest ground for regarding 'pollutions,' whether they arise from agricultural or manufacturing industries, as primary causes of salmon disease, they may have a most important secondary influence; they may, in fact, determine whether in any river the disease shall be sporadic or epidemic."

Taking, therefore, the foregoing statement into consideration, I think it may safely be assumed that pollution of some kind, the nature of which has yet to be discovered, is indirectly, if not directly, the cause of the disease called Saprolegnia ferax.

Attempts have been made to stamp out salmon disease, by removing from the rivers all diseased fish that can be laid hands on, and burying them or otherwise destroying them. When disease breaks 
SAPROLEGNIA FERAX, SALMON DISEASE. 155

out among cattle the whole herd are slaughtered indiscriminately; if one were suffered to live, disease would certainly break out among the next lot it came in contact with, and as saprolegnia is an infectious or contagious disease, why should not the same principle be applied to fish? But it would be impossible to destroy every salmon affected with disease in any river, and therefore to endeavour to stamp it out by such means, although helping to lessen the chances of infecting healthy fish, must end, as it has ended, in failure.

The only available cure at present known for salmon disease is salt water, as diseased fish which are fortunate enough to reach the sea, apparently get cured, but it is not certain that the cure is complete.

Salt water destroys the fungus adhering to the fish, and the sore created thereby may heal over; still, in many cases, the disease may lie dormant in the system of the fish, to break out again under conditions favourable to its development. This 
supposition leads me to consider a question I have often asked myself, viz. Why it is that so few early ascending salmon show any signs of being diseased ? I occasionally hear of disease during the spring months, but I do not remember ever to have caught a diseased fish myself during those months. On one occasion I caught a slightly diseased salmon in the Usk, during the early part of June, and there had been several caught in that river the previous April and May, but it is generally later on that the disease breaks out in a virulent form, the mortality being greatest among the spawning and spent fish.

May it not be possible that a cold temperature retards and a warm temperature accelerates the development of saprolegnia? The temperature of the sea being several degrees colder during the spring months than during the summer, may not this account for the fact that the disease seldom breaks out in the sea in fish in which it has lain dormant until the summer, when the temperature of the sea, as well as that of fresh water, has become 
SAPROLEGNIA FERAX, SALMON DISEASE. 157

warmer? This, of itself, may be the immediate cause of the reappearance of disease in rivers in which it is supposed to have died out. Salmon roam about in the sea in shoals, and should one of a shoal happen to be diseased, it would not be surprising if the whole shoal eventually exhibited disease after their arrival in fresh water. I am at a loss to account in any other way for the fact that so few early ascending fish are affected with saprolegnia. It would be interesting if a record were kept to show whether or not the spring had been a mild one in those years when signs of disease appeared amongst the early fish.

My remarks have been so far confined to saprolegnia among salmon, but it should not be forgotten that non-migratory fish, affected with the same disease, remain behind in the rivers after all the surviving diseased salmon have gone to sea. These fish have no access to a salt-water bath, and the question arises as to what becomes of them. Many must die as well as salmon, but we do not hear of 
any of them having been removed and buried along with diseased salmon. The very existence of these smaller vehicles of pestilence appears to have been entirely ignored by those who are advocates for stamping out the disease by removal. Whether they all eventually die, or whether they recover, there is no evidence forthcoming to show. Professor Huxley states that there are fungi, other than that called saprolegnia, which devour and destroy saprolegnia; therefore it is just possible that one or other of these destroying fungi may have come in contact with such diseased non-migratory fish as have survived, and that some of them have thus got cured. The saprolegnia on the dead fish may have been destroyed in like manner, and it is thus that the disease has disappeared in rivers, to break out again on the reappearance of salmon, in which it may have lain dormant during their sojourn in the sea.

The foregoing theory may appear to the reader to be more or less untenable. Granted that it is so, it. has still the merit that it is founded to a certain 
SAPROLEGNIA FERAX, SALMON DISEASE. I59 degree on fact, which cannot be said of many theories that are propounded in these days; and I merely suggest it for what it is worth. For the rest, it seems to me that, instead of spending more time and money in fruitless efforts to stamp out saprolegnia by such means as is proposed in one of the provisions of the new Scotch Fisheries Act, which was to have been brought in in the session of I888, it would be far wiser to wait patiently until further researches have been made, and the results of experiments by scientists, whose attention is still being given to the question, have been made known. 



\section{APPENDIX A.}

Page 60.-As the law at present stands, the close time is limited in Scotland to 36 hours, viz. from 6 p.m. on Saturday to 6 a.m. on Monday. In England to 42 hours, from 12 o'clock noon on Saturday to 6 a.m. on Monday (but this time can be extended under certain circumstances to 48 hours). In Ireland to 48 hours. I could never understand on what grounds the foregoing close times were so fixed. The climate of Scotland being many degrees colder in winter and early spring than in Ireland, early salmon make much slower proyress up Scotch rivers than they do in Irish rivers in consequence, and if the figures had been reversed and Scotland had been given 48 hours, and Ireland 36 hours, there would have been some foundation in reason for the proportion; but a 36 hours' close time is totally inadequate to meet the requirements of many Scotch rivers. My remarks do not apply to rivers in which there is no netting above the tideway, but in rivers where nets are so at work a 36 hours' close time is a farce, and should be extended to at least 48 hours, with power under certain circumstances to extend it to 60 hours, provided always that should any extension be granted, no new netting stations should be established above the existing ones. 


\section{APPENDIX B.}

SINCE the foregoing pages were written the Local Government Act, I888, has come into force, conferring upon the County Councils a certain control over our English and Welsh fisheries. It appears that County Councils are enabled to appoint conservators other than ex-officio members with power to make bye-laws. Herein, I am convinced, the Legislature have made a most serious mistake. For what does this mean? It means simply this: that with the exception of ex-officio members, who will be a minority at board meetings, conservators will be appointed who know nothing about salmon fisheries and probably care less, and who therefore are scarcely qualified to watch over the interests of the rivers that lie wholly or partially within their jurisdiction. Indeed, in the present reign of political doctrinaires, there will be no lack of councillors who would like nothing better than to hand over private rights of fishing to the general public. Nor can we hope from the constitution of these councils that sound economic considerations, will prevail to save us from the risk of interested alterations in the annual and weekly close times, such as must bring in their train disastrous consequences for our English and Welsh salmon fisheries. Before the passing of the Local 
Government Act the then existing arrangements were far from satisfactory, as I have endeavoured to point out ; the new transfer of powers seems to me a move from bad to worse. It is true that Mr. Berrington, our Chief Inspector, is the right man in the right place, and as long as he remains at his post we may feel confident that he will do his best to avert disaster; but, should the Board of Trade in a weak moment be induced to give their sanction to some mischievous scheme recommended by any board of conservators as constituted under the new Act, the Chief Inspector is powerless to help us. Altogether, I think the prospect a most gloomy one. 
LONDON:

PRINTED BY GILBERT AND RIVINGTON, IIMITED, ST. JOHN'S HOUSE, CLERKENWELL ROAD. 





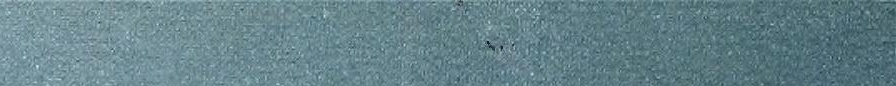

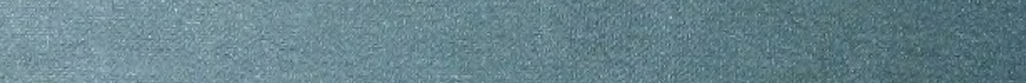

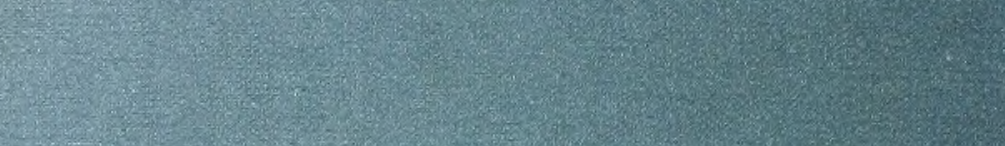

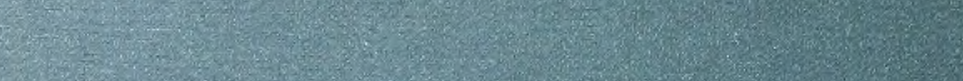

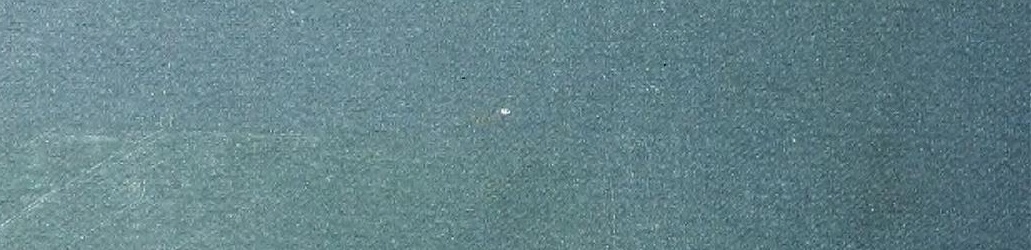

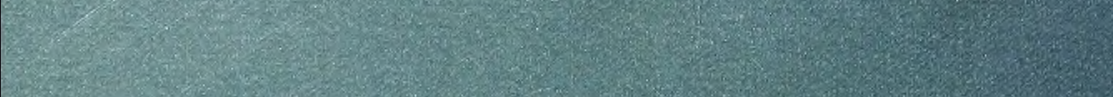

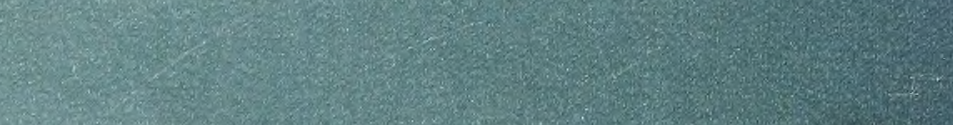

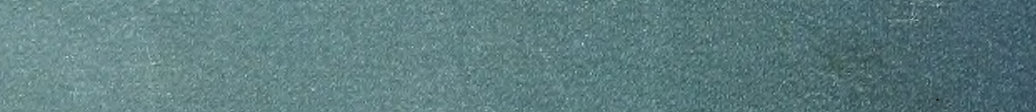

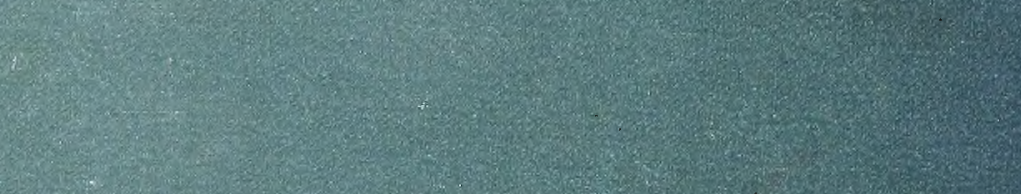

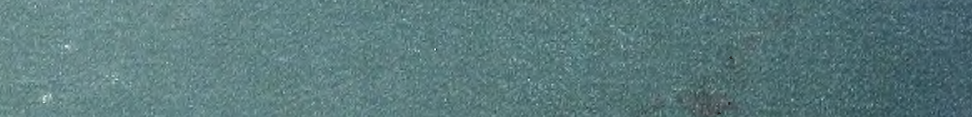

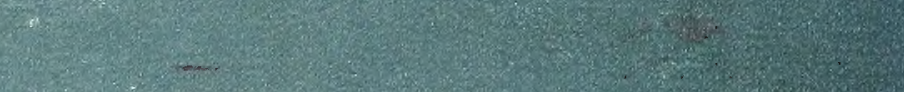

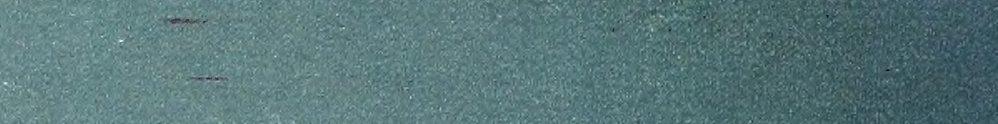

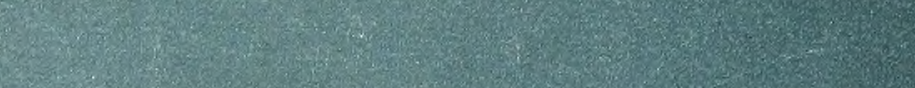

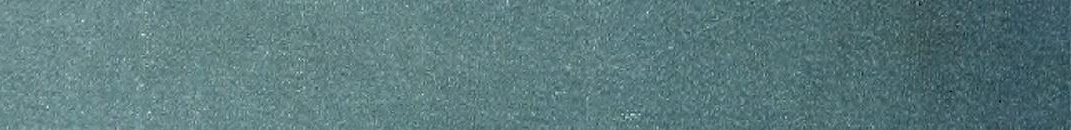

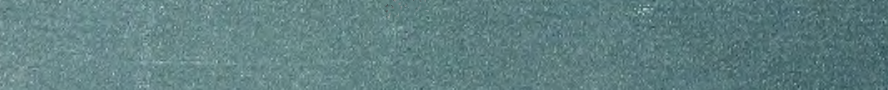

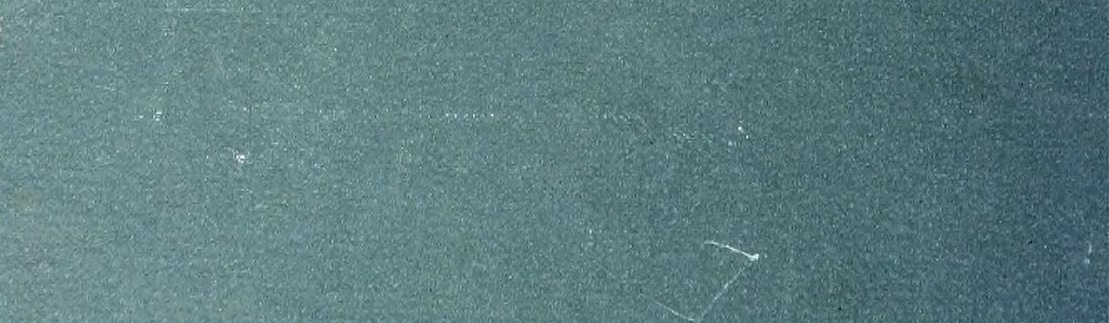

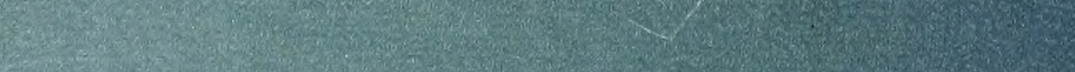

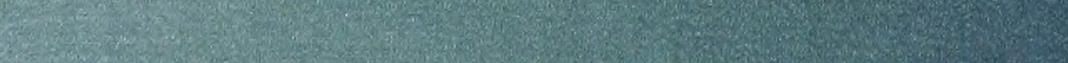

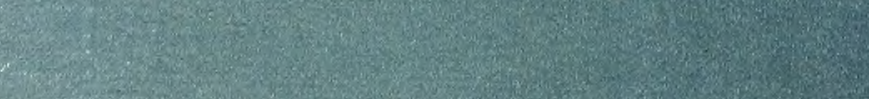

